総合論文

\title{
有機遷移金属錯体を活用する 付加環化反応
}

\author{
Organotransition Metal Catalyzed Cycloaddition
}

Kenji Itoh*

\begin{abstract}
Transition metal catalyzed cycloaddition and related carbon-carbon bond forming reactions are described. Zerovalent palladium species catalyze the cyclocoupling between two molecules of electron-deficient alkynes or 1, 6-diynes and alkenes or alkynes. Intramolecular $[2+2+2]$ cycloaddition of dimethyl 5,10-dioxa-tetradeca-2, 7, 12-triynediolate induces bis-annulation of 2,5-dihydrofuran to give the corresponding phthalate derivative involving two 2,5-dihydrofuran moieties. In stoichiometric reaction with $\mathrm{Pd}_{2}(\mathrm{dba})_{3}$, the triyne furnishes a planar three-coordinated triyne complex of palladium. The cationic pentamethylcyclopentadienylruthenium(II) fragment, $\mathrm{Cp}^{*} \mathrm{Ru}^{+}\left(\mathrm{Cp}^{*}=\right.$ $\left.\eta^{5}-\mathrm{C}_{5} \mathrm{Me}_{5}\right)$ induces [4+4] cycloaddition of butadiene and isoprene. The pentamethylcyclopentadienylruthenium(II) chloride fragment, $\mathrm{Cp}^{*} \mathrm{RuCl}$, is a highly efficient catalyst to induce [2+2+2] cycloaddition of 1,6-diynes with several carbon-carbon and carbon-nitrogen multiple bonds to furnish bicyclic arenes, cyclohexadienes, pyridines, 2,2'-dipyridyl derivatives, and pyridones fused by cyclopentane, 2,5-dihydrofuran or pyrrolidine moieties. An indenylchlororuthenium(II) fragment induces unprecedented catalytic bis-cyclopropanation in the reaction of 1,6-diynes with strained bicycloalkenes.
\end{abstract}

Key words: $\mathrm{C}-\mathrm{C}$ bond formation, cycloaddition, transition metal catalysis, ruthenium, palladium, 1,6-diynes, conjugated dienes, bicycloalkenes, nitriles, isocyanates

\section{はじめに}

遷移金属錯体を触媒とする炭素一炭素結合形成反応 が, 全合成を中心とする精密合成化学の方法論として積 極的に導入されるようになった周。それら反応の多く は，石油化学をはじめとする工業的プロセスの合成反応

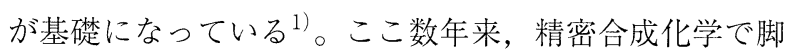
光を浴びているメタセシス反応も, ブテンをエチレンと プロピレンに不均化させる不均一系モリブデン触媒プロ セスとして登場した。その有機金属化学的研究から発展 したルテニウム錯体触媒反応が，オレフィン合成で汎用 された Wittig 反応のアトムエコノミカルな欠点を補う だけでなく, 広範囲の員数をもつ環状骨格の構築が可能 なすぐれた代替反応として，1990年代後半から積極的 に精密合成化学と開環重合の分野に取り入れられてい

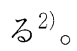

触媒的炭素-炭素結合形成で使われる頻度が最も多い 反応群は, 扦入反応 (Insertion)に基礎を置く触媒反応で

2000 年有機合成化学協会賞 (学術的なもの) 受賞

* 名古屋大学大学院工学研究科物質制御工学専攻

* Department of Molecular Design and Engineering, Graduate School of Engineering, Nagoya University
ある ${ }^{3)}$ 。水素化, 種々のヒドロメタル化, ヒドロホルミ ル化を含む多様なカルボニル化, Heck 反応, SHOP プ ロセス, Ziegler-Natta 拉よび Kaminsky 触媒発見以来 目覚ましい発展を遂げつつある，アルケンの立体特異的 重合が代表的な例である。

触媒的精密合成反応で重要なもう一方の柱は，トラン スメタル化(Transmetallation)を酸化的付加 (Oxidative addition)および還元的脱離 (Reductive elimination)と組 み合わせた多くのクロスカップリング反応である4)。こ の分野に㧍ける我が国の研究者の貢献は目覚ましく, 玉 尾-熊田 $(\mathrm{Mg} / \mathrm{Ni})$, Stille $(\mathrm{Sn} / \mathrm{Pd})$, 哣頭-Castro $(\mathrm{Cu} / \mathrm{Pd})$, 鈴木一宮浦 $(\mathrm{B} / \mathrm{Pd})$, 桧山一畠中 $(\mathrm{Si} / \mathrm{Pd})$ など のすぐれた研究が世界を先導したことはよく知られてい る。

上記 2 つ変換と異なる触媒的炭素-炭素結合形成反 応様式に，メタラサイクル中間体を経由する触媒反応が ある。遷移金属錯体触媒の幕開けとなった歴史的な Reppe によるアセチレンの 4 量化によるシクロオクタテ トラエン合成 ${ }^{5)}$, Wilke一門による共役ジエンからの 4, 6, 8, 10, ならびに 12 員環合成 (スキーム 1 : 共役ジエン の環化二一三量化は, ビスアリル金属中間体を経由して 進行するが，このビスアリル中間体も一種のメタラサイ クルである $)^{6)}$, 山崎一若槻によるメタラシクロペンタジ 


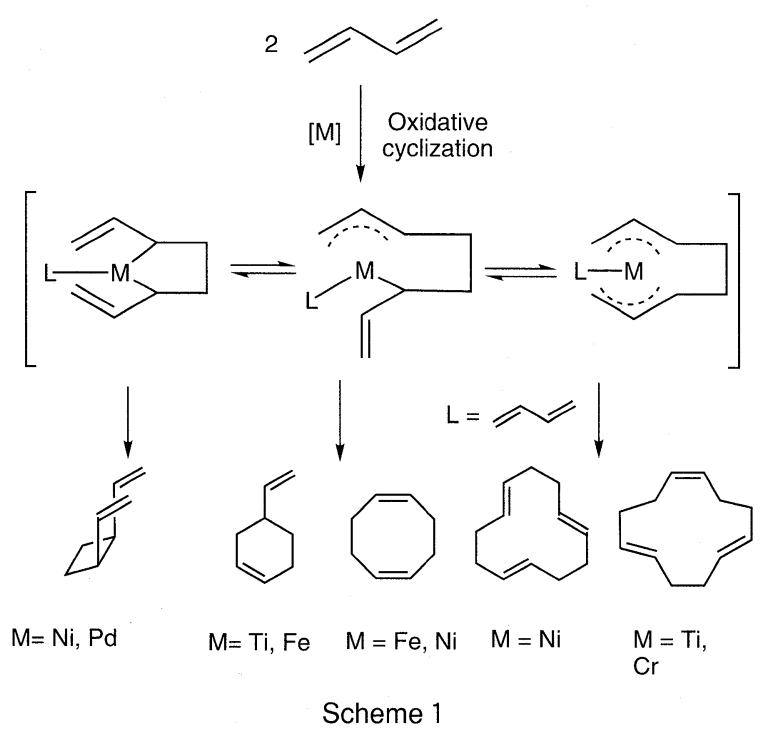

エンを経由するアルキンの環化三量化，P Pauson-Khand 反応 ${ }^{8)}$ ，が代表的な例である。先に記したオレフィンメ タセシスや，森らによるエンインやアルキンのメタセシ スもこの範疇に入る ${ }^{2 \mathrm{e}, 2 \mathrm{f})}$

メタラサイクル中間体を経由する触媒反応の魅力は, 複数の安定な不飽和分子から出発して, 複数の結合を一 挙に形成させ，環状分子骨格を付加環化形式で構築でき るところにある。

2 電子移動を伴う酸化還元過程が可能な低原子価状態 にある遷移金属活性種と，それぞれ $2 \mathrm{~m}, 2 \mathrm{n}$ 個の $\pi$ 電子 をもつ 2 つの不飽和分子から，2つの金属-炭素結合と 1 つの炭素-炭素結合が形成されて環化してメタラサイ クル錯体が生成する。そのさい金属中心は酸化状態が形 式的に 2 価増加する。この過程を「酸化的環化」(Oxidative cyclization)，その逆反応を「還元的開裂」(Reductive fragmentation) と呼び, 酸化的付加 - 還元的脱離と 区別する必要がある。酸化的環化過程は， $\left[\mathrm{d}^{2}+2 \mathrm{~m}+\right.$ $2 \mathrm{n}]$ 付加環化とみなすことによって有機化学の付加環化 反応と，還元的開裂はキレトロピー反応と刘応させるこ とができる。

\section{1. メタラシクロペンタジエンの歴史的背景と反応}

Reppeにより 1948 年に報告された，ニッケル触媒を 用いるアセチレン 4 分子の形式的な $[2+2+2+2]$ 付加環 化は錯体触媒反応のさきがけである ${ }^{5 a)}$ 。この歴史的な Reppeのシクロオクタテトラエン生成の機構が，30 年

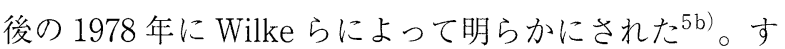
なわち，ニッケルを中心金属とする 2 個のメタラシクロ ペンタジエン中間体が，複核配位子場でカップリングす ることによって進行する機構である(スキーム 2)。

メタラシクロペンタジエン錯体を合成反応へ展開させ た先駆者は, 山崎博史, 若槻康雄両博士であり, シクロ

\section{Reppe (1948)}

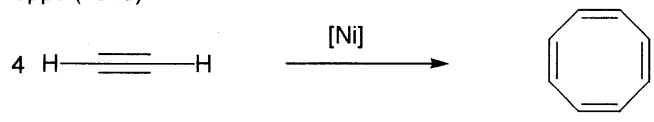

Wilke's bimetallic mechanism (1978)

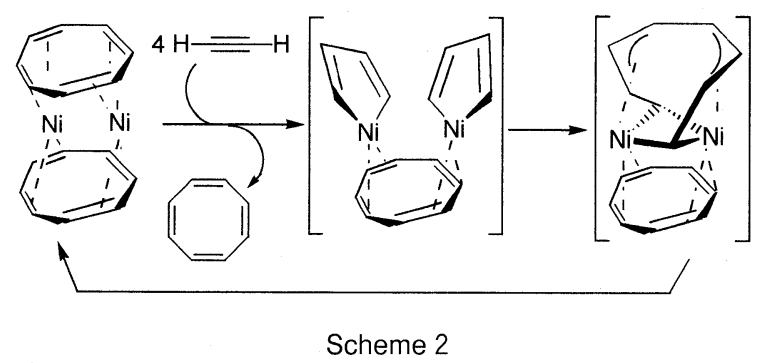

ペンタジエニルコバルト (I) 活性種から生じるコバルタ シクロペンタジエン中間体のアルケン，アルキン，ニト リル，イソシアナートなどとの触媒的㧍よび量論的環化 カップリングが詳しく検討されだ)。またBönnemann のCo 触媒によるピリジン合成も山崎とほぼ同時に発表 された ${ }^{9)} 。$ 一方 Vollhardt は 1975 年以来, 有機化学者の 視点から「基質の分子内化設計」の概念を導入して山崎ら の触媒系を発展させ，2つのアルキン部位を分子内化し たジイン類や，その一方をシアノ基に変えたシアノアル キン類を基質にして，ステロイド骨格構築と複素環合成 に成功し大きな注目を浴びた ${ }^{10)}$ 。筆者がこの分野に足を 踏み人れた 1970 年代は，コバルト(山崎)，ロジウム (Müller)，パラジウム (石井, Maitlis)を中心にほと んどの遷移金属元素のメタラシクロペンタジエン錯体が 合成されただけでなく，有機合成化学への展開が急速に 進んだ時代であった ${ }^{7-11)}$ 。

\section{2. メタラシクロペンタジエンの反応様式}

3 分子のアルキン間の $[2+2+2]$ 付加環化によるベン ゼン環形成を環化カップリングの例として考えよう。

2 分子のアルキンと低原子価金属活性種の酸化的環化 によって，メタラシシロバンタジムン中間体 1 が生成す る(スキーム 3$)$ 。

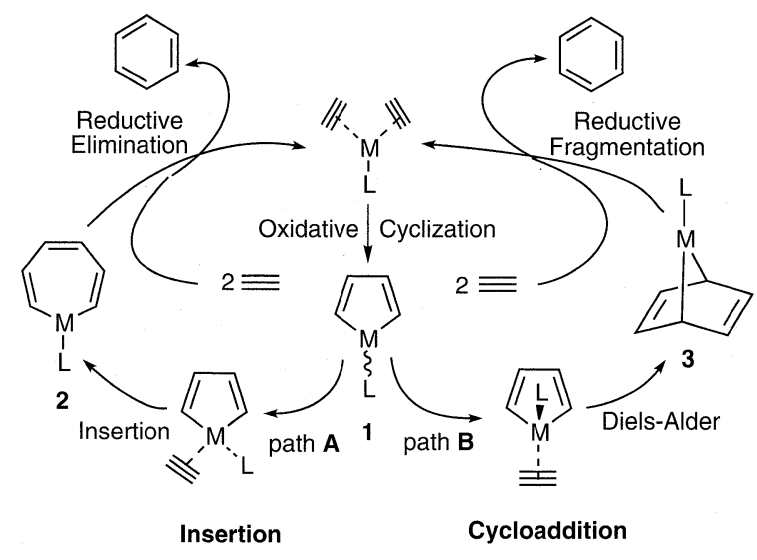

Scheme 3 
生成したメタラシクロペンタジエン中間体の第三の不 飽和分子であるアルキンとの反応については，1の一方 の金属一炭素結合への配位一挿入によるメタラシクロへ プタトリエン中間体 2 への環拡大と, 引き続く還元的脱 離による低原子価活性種の再生と放出を伴った 6 員環生 成物の生成機構が広く受け入れられてきた(スキーム 3 の触媒サイクル A)。その主な理由は, 有機金属化学者 (往時の筆者も含めて)にとって, 導入された不飽和基質 がまず金属中心と配位相互作用したのち，あらかじめ存 在する金属一炭素結合に挿入する配位一挿入機構が多く の有機金属反応で確立されていたためであろう。

しかし挿入過程で生成すると予想されるメタラシクロ ヘプタトリエン錯体が単離され確実に構造決定された例 は極めて少なく，しかもそれらから金属フラグメントを 還元的脱離して 6 員環を形成することを実験的に証明し

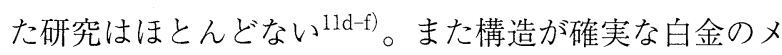
タラシクロヘプタトリエン錯体の X 線構造解析結果で は, 分子内配位二重結合部位である C 4-C 5 部位におけ る立体化学がトランス配置となるため, 還元的脱離すべ き 2 本の金属一炭素結合が金属中心にトランスに配置し てしまい還元的脱離による炭素一炭素結合形成には適さ ない配置となってしまうことを示唆している11a, b)。

挿入による環拡大機構と全く異なる反応機構として, メタラシクロペンタジエン中間体 1 を Diels-Alder 反応 に扔けるジエン成分の金属類縁体と考え，[4+2]付加環 化が第三成分との間で進行する経路を考えることができ る(スキーム 3 の触媒サイクル B )。その結果生成する

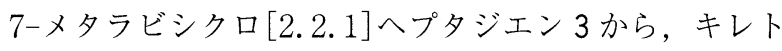
ロピーと類似した還元的開裂 (Reductive fragmentation）が起これば，芳香族炭化水素を生成するとともに， 金属活性種は低原子価状態で再生できる。

これら経路 $\mathrm{A}$ 抢よび $\mathrm{B} の 2$ 種類の反応経路のどちら が有利かは, 金属錯体の配位子場の構造に依存すると考 えられる。これまで異なるアルキン間の $[2+2+2]$ 付加 環化形式のカップリングが進行した山崎- 若梘一 Vollhardt らのコバルト触媒系と, のちに述べる筆者ら のルテニウム触媒系は, いずれもシクロペンタジエニル 系配位子を含む「ピアノ椅子型」の配位子場に特徽があ る。この鏡面対称をもつメタラサイクル中間体の配位子 場では，環状配位子によって基質の接近面が強く規制さ れており，第三の基質となるアルキンがメタラサイクル の 2 本の金属一炭素結合に対して立体障害の最も少な い，環状配位子が存在する面と逆の鏡面対称面から接近 することになる(図 1)。この経路は Diels-Alder 形式の 遷移状態へ容易に移行できる。

一方, 平面 4 配位構造をもつ配位子場で単座の支持配 位子が存在すると，第三の基質の接近方向は，2本の金

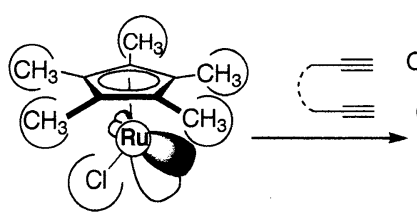

$R u(I I)\left(d^{6}\right)$

14 electron species
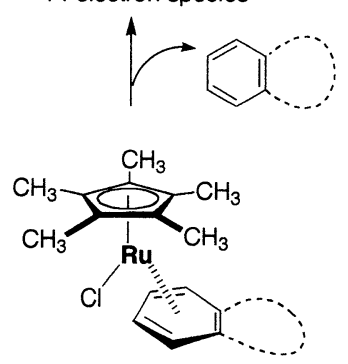

$\mathrm{Ru}(I I) ; 18$ electron intermediate

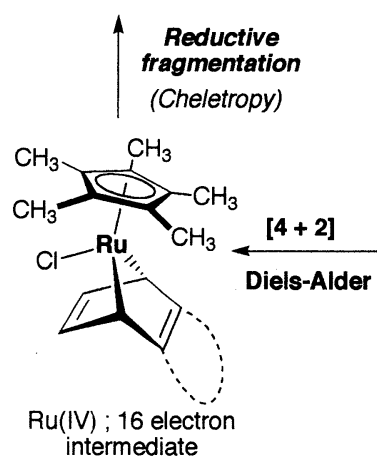

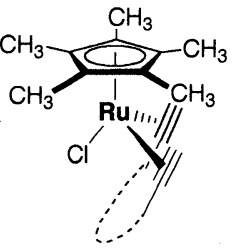

$\mathrm{Ru}(I I) ; 18$ electron intermediate

Oxidative $\checkmark$ cyclization
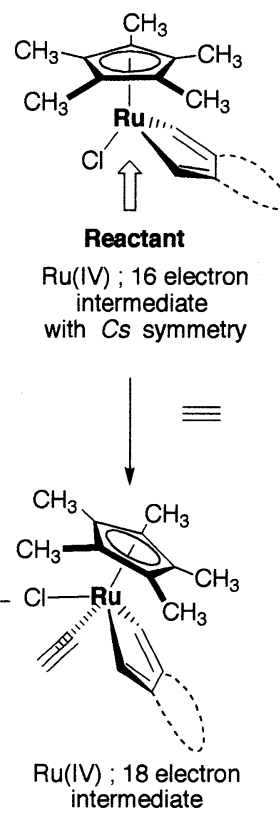

Fig. 1 Diels-Alder mechanism of the $\mathrm{Cp}^{*} \mathrm{RuCl}$ fragment for the $[2+2+2]$ cycloaddition of 1,6 -diynes with alkynes.

属一炭素結合のいずれかに平行になるため挿入一環拡大 に適した遷移状態へ移行することができる。しかしこの 場合でも，第三の基質が平面の上下方向から接近すれば Diels-Alder 形式の遷移状熊へ進むことも可能である。

筆者の研究チームでは, 1970 年代後半からパラジウ ムを中心金属とするメタラシクロペンタジエン錯体の有 機金属化学を研究していた。その過程で電子欠損性アル キン 2 分子とアルケン類との $[2+2+2]$ 付加環化形式に よる触媒的環化カップリングを見いだしたことを端緒と してメタラサイクルを経由する触媒的な環化カップリン グの研究を進めてきた。最近の数年間はシクロペンタジ エニル系配位子で接近方向を規制したルテニウム (II) 錯 体を触媒とするジエンならびにジインを基質とした付加 環化形式の触媒反応を検討している。本論文ではその概 要を説明する12)。

\section{3. パラジウム錯体触媒をもちいる炭素環形成と関連 反応}

電子欠損性アルキンであるアセチレンジカルボン酸ジ メチル (DMAD)を, Pd(0)-dba 錯体と反応させると, 酸化的環化が起こり, メタラシクロペンタジエン錯体 
$\left[\mathrm{Pd}\left(\mathrm{C}_{4}\left(\mathrm{COOCH}_{3}\right)_{4}\right)\right]_{\mathrm{n}}, 4$ が沈殿してくる ${ }^{11 \mathrm{~b}, \mathrm{c})} 。 4$ は, $\alpha$-位のカルボニル酸素が分子間で架橋した不溶性の分 子集合体である ${ }^{13,14)}$ 。2 価錯体 4 は, DMAD 2 分子と工 チレン，スチレン，ノルボルネン誘導体などのアルケン との $[2+2+2]$ 付加環化の良好な交差型カップリングの 触媒となることを 1976 年に報告した $\left(\right.$ スキーム 4) ${ }^{13)}$ 。

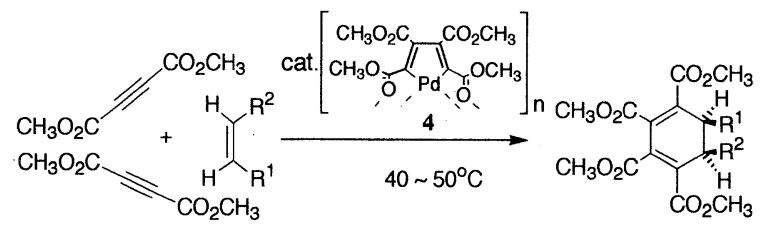

Alkene: Ethylene (2 atm; 96\%), Styrene (87\%), Norbornene (94\%)

Scheme 4

反応が終了すると，パラジウム・ミラーが析出するこ とから, 超高活性な naked $\operatorname{Pd}(0)$ が真の活性種と考え た。 $\mathrm{Pd}(0)$ は $\mathrm{d}^{10}$ の電子配置であるため，用いることが できる基質としては, DMADのような強力な電子欠損 性アルキンが適していた。

アルキンの交差環化三量化で，非対称アルキンを基質 の一部に使うと導入される異なるアルキンの組み合わせ により付加環化体が多数生成するだけでなく，それぞれ に多くの位置異性体が存在する。極端な例として，もし すべて異なった 3 種類の非対称アルキンを交差カップリ ングさせて望む多置換ベンゼン誘導体だけを得ようとす ると, $[2+2+2]$ 付加環化生成物は, 各成分の導入数と 位置選択性をすべて考慮に入れれば 30 種類を超える生 成物が発生する可能性があり合成反応として全く意味を なさない。アルキンの環化三量化を交差形式で位置およ び化学選択的に進行させるためには, 複数の不飽和部位 を分子内化する以外に解決法はない。

最近になってメタラシクロペンタジエンを構成する 2

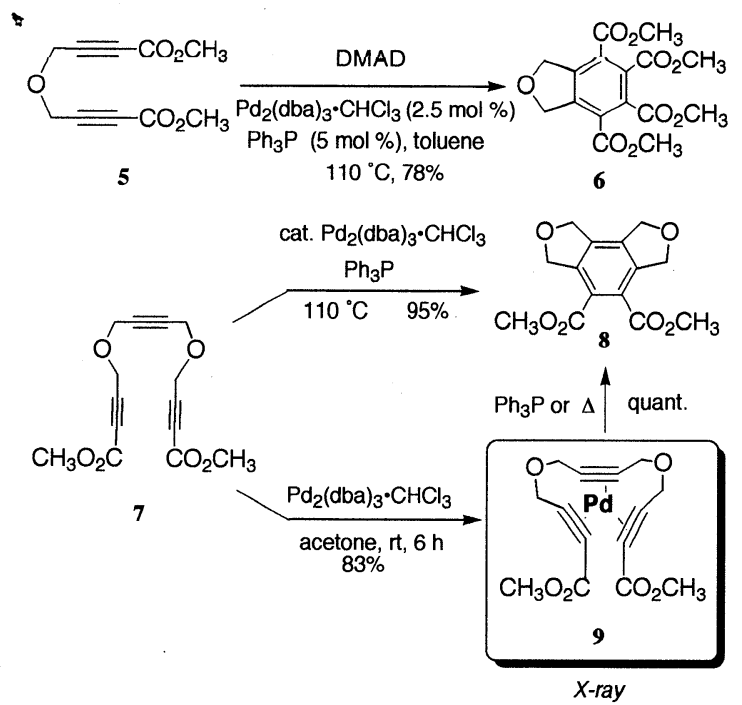

Scheme 5
つのアルキンをジプロパルギルエーテルとして分子内化 したジイン 5 と DMAD を反応させたところ，オキサジ ヒドロインダン誘導体 6 が選択的に生成した(スキーム 5) ${ }^{15)}$ 。さらに，[2+2+2]付加環化を起こすアルキン部 位をすべて分子内化したトリイン 7では, $\mathrm{Pd}(0)-\mathrm{Ph}_{3} \mathrm{P}$ 触媒存在下にジヒドロイソベンゾフラン 8 のみを選択的 に生成することができた ${ }^{16)}$ 。また 7 を等量の $\mathrm{Pd}_{2}(\mathrm{dba})_{3}$ 錯体と反応させたところ，3つのアルキン部位が平面配 位されたトリイン錯体 9 が生成した。9は加熱するか $\mathrm{Ph}_{3} \mathrm{P}$ を加えることにより 8 が生成することも確認し $た^{16)}$ 。

別のアプローチとして, DMAD 1 分子とアルケン 2 分子との 3 成分カップリングを実現しようと計画した。 先にも記したように， $\pi$ 求核的な $\operatorname{Pd}(0)$ 活性種の電子状 態を求電子側へ制御するため, ダミー配位子として強力 な電子欠損性をもち炭素結合形成には不活性な無水マレ イン酸を配位子に導入した 2 価的性格をもつ $\mathrm{Pd}(0)$ 錯体 10 を合成した ${ }^{17)}$ 。10 と大過剩の末端オレフィンの混合 物に DMAD をゆっくり加えることにより，DMADのア ルキン部位に 2 つのアルケンが水素移動を伴いつつ syn 反マルコフニコフ付加した, 拡張エン反応形式の 3 成分 1 段連結反応が進行することを明らかにした(スキーム 6) ${ }^{18)}$ 。

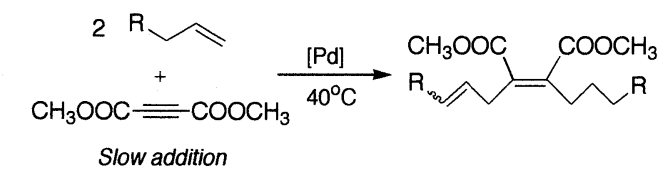

\begin{tabular}{|c|c|c|c|c|c|}
\hline Alkene & $\mathrm{mmol}$ & $\begin{array}{l}\text { DMAD } \\
\text { (mmol) }\end{array}$ & $\begin{array}{l}\text { Catalyst } \\
\text { (mmol) }\end{array}$ & $\begin{array}{l}\text { Yield } \\
(\%)\end{array}$ & \\
\hline$\widehat{\sim}=$ & $\begin{array}{l}26.0 \\
30.2\end{array}$ & $\begin{array}{l}4.10 \\
4.27\end{array}$ & $\begin{array}{l}0.24 \\
0.26\end{array}$ & $\begin{array}{l}76 \\
68\end{array}$ & \\
\hline$\widetilde{W}^{\prime}$ & $\begin{array}{l}20.9 \\
22.3\end{array}$ & $\begin{array}{l}3.40 \\
3.53\end{array}$ & $\begin{array}{l}0.24 \\
0.25\end{array}$ & $\begin{array}{l}83 \\
75\end{array}$ & O \\
\hline
\end{tabular}

Scheme 6

\section{4. シクロペンタジエニルルテニウム錯体の有機金属 化学 : Ru(II) ↔Ru(IV) 酸化還元過程の触媒的炭 素-炭素結合形成への有用性}

ルテニウム 2 価錯体 $\mathrm{CpRuCl}(\mathrm{CO})_{2}\left(\mathrm{Cp}=\eta^{5}-\mathrm{C}_{5} \mathrm{H}_{5}\right)$ を 過剩の塩化アリルと加熱すると, 酸化的付加して対応す るルテニウム 4 価アリル錯体 $\mathrm{CpRu}\left(\eta^{3}-\mathrm{C}_{3} \mathrm{H}_{5}\right) \mathrm{Cl}_{2}$ を生成 する ${ }^{19)}$ 。またペンタメチルシクロペンタジエニル $\left(\mathrm{Cp}^{*}\right.$ $\left.=\eta^{5}-\mathrm{C}_{5} \mathrm{Me}_{5}\right)$ アリル錯体は, 3 価錯体 $\left[\mathrm{Cp}^{*} \mathrm{RuCl}_{2}\right]_{2}$ のア リル化合物 $\left(\mathrm{C}_{3} \mathrm{H}_{5}-\mathrm{X} ; \mathrm{X}=\mathrm{Cl}, \mathrm{Br}, \mathrm{OH}, \mathrm{OAc}, \mathrm{SPh}\right)$ との $\mathrm{SH}$ 2 機構によるアリル基移動反応で合成できる ${ }^{20)}$ 。

これらのルテニウム 4 価アリル錯体 $\left(\eta^{5}-\mathrm{C}_{5} \mathrm{R}_{5}\right) \mathrm{Ru}$ $\left(\eta^{3}-\mathrm{C}_{3} \mathrm{H}_{5}\right) \mathrm{X}_{2}(\mathrm{R}=\mathrm{H}$ または $\mathrm{Me})$ は，等量のメチルリチ ウムと反応させるとモノメチル 4 価錯体が, トリメチル 
アルミニウムとの反応によりジメチル 4 価錯体が，いず れも空気中で安定な錯体として単離できる21)。

これらのアルキル・アリル錯体は, 中性配位子の存在 下に加熱すると，メチル基とアリル基問で還元的脱離し て炭素-炭素結合を形成する。この結果は Ru(II) と Ru (IV) 間の 2 電子酸化還元過程が炭素-炭素結合形成の推 進力として利用できることを示す。

さらに 4 価アリル錯体 $\left(\eta^{5}-\mathrm{C}_{5} \mathrm{R}_{5}\right) \mathrm{Ru}\left(\eta^{3}-\mathrm{C}_{3} \mathrm{H}_{5}\right) \mathrm{X}_{2}$ を, 共役ジエンの存在下でトリエチルアルミニウムと処理す ると，モノエチル中間錯体の $\beta$-脱離により生に゙るアリ ル (エチレン)ヒドリド $\mathrm{Ru}(\mathrm{IV})$ 中間体の還元的脱離によ り，プロペンとエチレンを放出して対応するルテニウム （II）共役ジエン錯体 $\left(\eta^{5}-\mathrm{C}_{5} \mathrm{R}_{5}\right) \mathrm{Ru}\left(\eta^{4}-\mathrm{C}_{4} \mathrm{H}_{5} \mathrm{R}^{\prime}\right) \mathrm{X}$ が合成で きる。 $\mathrm{R}=\mathrm{CH}_{3}$ の $\mathrm{Ru}(\mathrm{II})$ 共役ジエン錯体 $\mathrm{Cp}{ }^{*} \mathrm{Ru}\left(\eta^{4}\right.$ $\left.\mathrm{C}_{4} \mathrm{H}_{5} \mathrm{R}^{\prime}\right) \mathrm{X}$ は, ジエンの存在下に, 3 価錯体 $[\mathrm{Cp}$ * $\left.\mathrm{RuCl}_{2}\right]_{2}$ をメタノール中で帚鉛末で還元することによっ て，より簡便に大量合成ができるようになった ${ }^{24)} 。$

ペンタメチルシクロペンタジエニル $\left(\mathrm{Cp}^{*}=\eta^{5}-\mathrm{C}_{5} \mathrm{Me}_{5}\right)$ 配位子は，メチル側鎖の電子供与性によって強く金属中 心と配位相互作用し，側鎖の立体的かさ高さにより環の スライドが起こらない。そのため, 配位子場への基質の 接近方向を的確に規制できるだけでなく，開いた傘のよ うにコンパクトな反応場を提供する信頼性の高い電子供
与性 $\eta^{5}$-配位子である (図 1)。

\section{5. 共役ジエンの量論的および触媒的オリゴメリゼー ション}

ブタジエン錯体 $\mathrm{CpRu}\left(\eta^{4}-\mathrm{C}_{4} \mathrm{H}_{6}\right) \mathrm{Br}\left(\mathrm{Cp}=\eta^{5}-\mathrm{C}_{5} \mathrm{H}_{5}\right)$ を ブタジエン存在下に銀トリフラートと処理すると, ブタ ジエン 2 分子がカップリングして生じた trans-1, 3, 7オクタトリエンを配位子とするカチオン性錯体 $[\mathrm{CpRu}$ $\left.\left(\eta^{2}, \eta^{2}, \eta^{2}-\mathrm{C}_{8} \mathrm{H}_{12}\right)\right] \mathrm{OTf}$ が得られる。この錯体を触媒と してブタジエンを低重合させると，ブタジエンの直鎖 3 量体のドデカテトラエン混合物が生成した(スキーム 7 ; 式 1) 23)。

一方, ペンタメチル類縁体 $\mathrm{Cp} * \mathrm{Ru}\left(\eta^{4}-\mathrm{C}_{4} \mathrm{H}_{6}\right) \mathrm{Br}$ を, 同様にブタジエンと銀塩存在下に反応させて得られるカ チオン性錯体は, X 線構造解析の結果 $c i s-1,3,7$-オク夕 トリエンが C 1-C 3 部位で $\eta^{3}$ 配位子, C 4 炭素が $\eta^{1}$ 配 位子，C 7-C 8 部位が $\eta^{2}$ 配位子として 12 電子種である $\mathrm{Cp}$ *ルテニウム (II) カチオンと結合した特異な配位構造 をもつことが明らかとなった ${ }^{24)}$ 。さらに，この錯体(ま たは原系の $\left.\mathrm{Cp}^{*} \mathrm{RuBr}\left(\mathrm{C}_{4} \mathrm{H}_{6}\right) / \mathrm{AgOTf}\right)$ を触媒として，ブ タジエンを低重合させたところ，ブタジエンが形式的に $[4+4]$ 付加環化して生じる 1, 5-シクロオクタジエン (cod)のみが選択的に生成した（スキーム７；式 2)。環

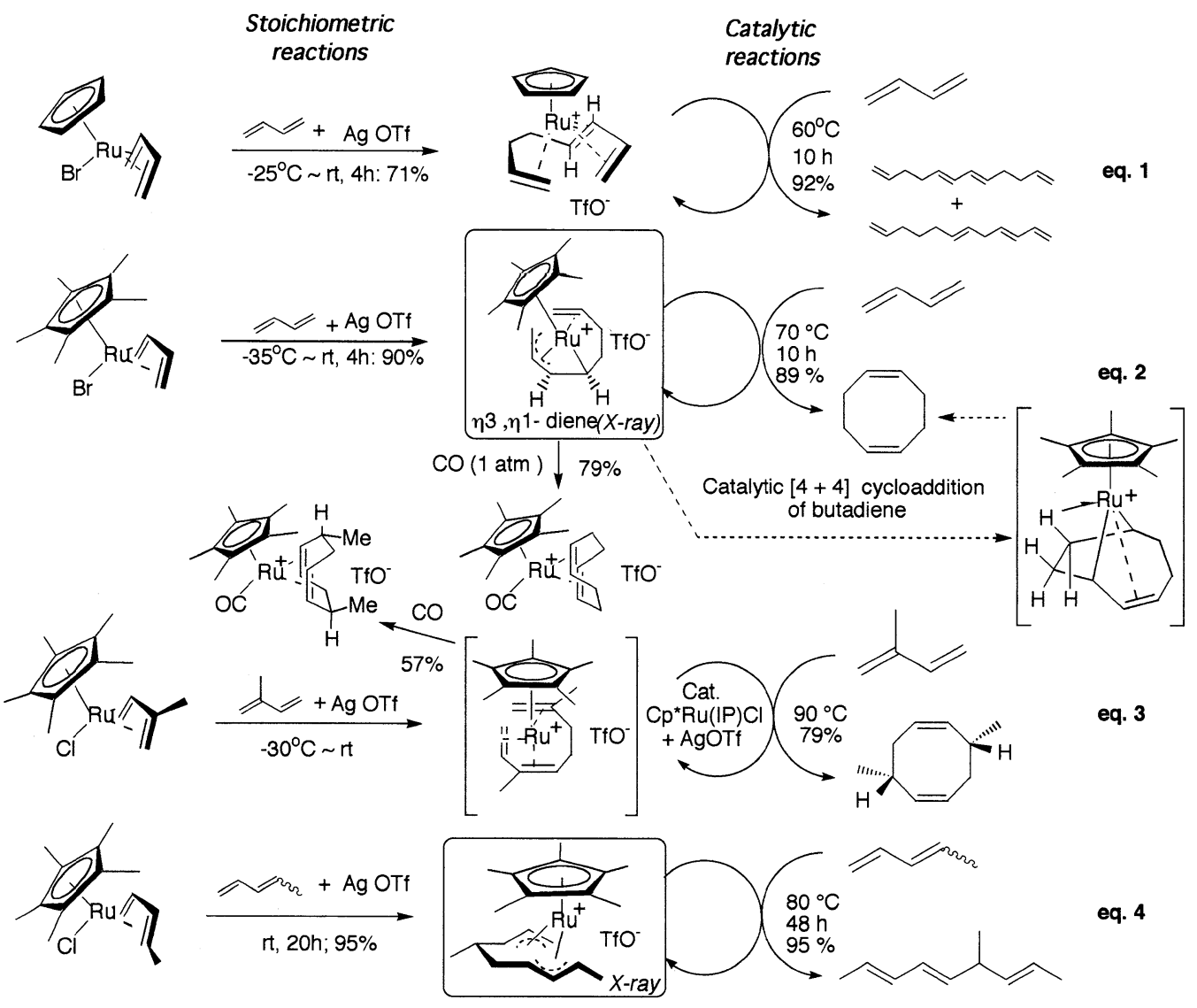

Scheme 7 
状オリゴマーの選択的生成はチタンやニッケルなどの第 一周期の遷移金属錯体触媒では一般的であるが，ルテニ ウムのような第二周期の遷移金属錯体触媒を用いた系と しては極めて異例である。その環化機構として，まず酸 化的環化によりビス $\left(\eta^{3}-\right.$ アリル)錯体が生成し，その水 素移動により cis-1,3,7-オクタトリエン配位子が生じた のち, 第二段目の酸化的環化によって, その両末端炭素 間で炭素-炭素結合を形成する。その結果，スキーム7 の式 2 と 3 の間に示したビシクロ [4.2.1]-9-ルテナ (IV)-2-ノネン中間体が形成され, その $\beta$-水素脱離と還 元的脱離による $\mathrm{C}-\mathrm{H}$ 結合の再結合を経て $\operatorname{cod} の 8$ 員環 が構築されたと考えられる。 8 員環構築のモデル反応と して，一酸化炭素による炭素-炭素結合形成を行い確認 した ${ }^{24)}$ 。イソプレンを基質にすると， [4+4]付加環化と 引き続くすみやかなアリル位 $\mathrm{C}-\mathrm{H}$ 結合の活性化と再結 合を経由する水素移動により，位置および立体選択的に cis-3, 7-ジメチルシクロオクタ-1, 5-ジエンが主に生成 した $(\text { スキーム } 7 \text {; 式 } 3)^{24)}$ 。

一方ピペリレンでは，触媒サイクルの初期生成物であ る酸化的環化段階生成物のビス $\left(\eta^{3}-\right.$ アリル) $\mathrm{Ru}(\mathrm{IV})$ 錯体

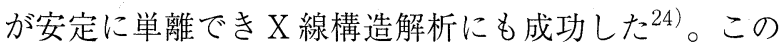
事実は， $[4+4]$ 付加環化の初期過程が酸化的環化による ビス・ $\pi$-アリル錯体の生成であることを強く示唆する。 さらに,このビス・アリル錯体はピペリレンの位置選択 的 head-tail 型直鎖二量体生成の再生可能な触媒となる (スキーム 7 ; 式 4)。

ルテニウム配位子場を利用した熱的禁制の $8 \pi$ 系付加 環化のもう 1 つの例として, 量論反応ではあるが筆者が 以前に発見した $\mathrm{Ru}(0)$ 配位子場を活用した環状共役トリ エンと単純アルキン類の $[6+2]$ 付加環化をスキーム 8

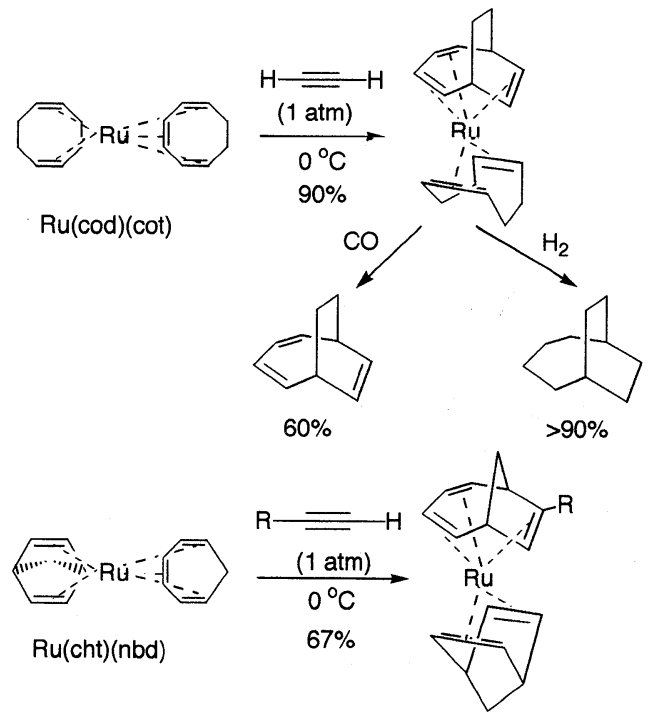

$\mathrm{R}=\mathrm{H}(67 \%), \mathrm{CH}_{3}(72 \%), \mathrm{Et}(69 \%)$

Scheme 8
に示す。この方法は，ビシクロ[4.2.1]デカン骨格が安 価な $\operatorname{cod}$ からわずか 2 工程で変換可能なトリエンの形 で構築できることに特徴がある。

この量論反応は $\mathrm{Cp}^{*} \mathrm{Ru}^{+}$系とは異なり $\mathrm{Ru}(0) \rightleftarrows \mathrm{Ru}$ (II)の酸化還元過程が $[6+2]$ 付加環化の推進力になっ ていることに注意してほしい。これに関連して光藤と近 藤らは，このレドックスチャンネルを活用した多くの触 媒的炭素一炭素結合形成および開裂反応を報告してい $3^{26)}$ 。

\section{6. ペンタメチルシクロペンタジエニルルテニウム錯 体を活用する 1,6 -ジインを基質とした触媒的付 加環化反応}

筆者の研究チームでは, ペンタメチルシクロペンタジ エニル $\left(\mathrm{Cp}^{*}=\eta^{5}-\mathrm{C}_{5} \mathrm{Me}_{5}\right)$ 配位子が， -2 価 $\left(\mathrm{d}^{10}\right)$ から 8 価 $\left(\mathrm{d}^{0}\right)$ にわたる多様な酸化状態が可能なルテニウムのう ち，高原子価状態にあるルテニウムを安定化し，規制さ れたコンパクトな反応場を提供する性質を活用して，新 たな触媒的炭素一炭素結合形成機能の発現に適用する研 究を行ってきた。この章では 4 価状態を $\mathrm{Cp}$ *配位子に より安定化させることによって $\mathrm{Cp}^{*} \mathrm{Ru}(\mathrm{II})$ と 1, 6-ジイ ンの酸化的環化を進行させ, 生成する $\mathrm{Cp} * \mathrm{Ru}(\mathrm{IV}) \times 夕$ ラサイクル中間体を付加環化反応に活用した最近のアプ ローチについて述べる (図 1 参照)。 $\mathrm{Cp} * \mathrm{RuCl}$ と 1,6-ジ インから生成するビシクロルテナシクロペンタジエンを Diels-Alder 反応におけるジエン成分と見なし，1，6-ジ インとアルキン, 環状アルケン，ニトリル，イソシア ナート，イソチオシアナートなどとの触媒的 $[2+2+2]$ 付加環化について述べる。

\section{$6.11,6$-ジインと末端アルキンの位置選択的付加 環化}

3 分子の異なるアルキンを触媒的に $[2+2+2]$ 付加環 化させ置換ベンゼン誘導体を合成しようとすると，極め て多数の生成物が生じ，合成化学的な意味引゙ないことは すでに述べた。

1,6-ヘプタジイン骨格の 2 つのアルキン部位は，第二 周期遷移金属元素の金属中心との同時配位に適している ため, $\mathrm{Ru}(\mathrm{II}) \rightarrow \mathrm{Ru}(\mathrm{IV})$ の酸化的環化によって高活性な 4 価 16 電子ビシクロ [3.3.0]メタラシクロペンタジエン 中間体を形成させることができる。2つのアルキン部位 と同時相互作用できる中性の遷移金属活性種として, 2 価 14 電子活性種“Cp* RuCl”を容易に発生することがで きる $\mathrm{Cp}^{*} \mathrm{RuCl}(\mathrm{cod})(\mathrm{cod}=1,5$-シクロオクタジエン)を 触媒前駆体として選択した。1,6-ヘプタジイン類と末端 アルキンを反応させたところ，交差環化カップリングが 選択的に進行し，対応するジヒドロインデン誘導体が高

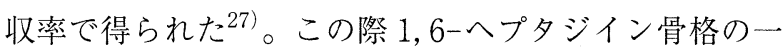


方に置換基を導入すると，その立体反発により，ブロッ クしている $\mathrm{Cp}$ *環と逆の面から接近する末端アルキン は置換基を避けるように付加環化して位置選択的にメ夕 置換体のみを生成した(スキーム 9 および表 1)。

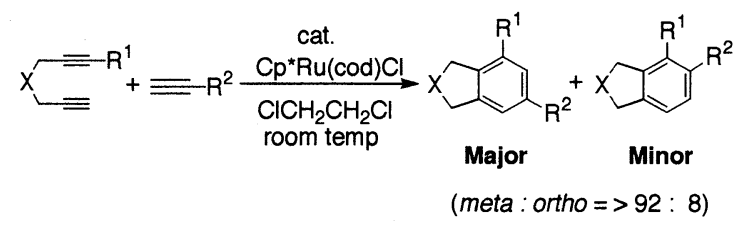

Scheme 9

Table 1 Regioselective $[2+2+2]$ cycloaddition of 1,6-diynes with alkynes.

\begin{tabular}{|c|c|c|c|c|}
\hline$x$ & $\mathrm{R}^{1}$ & $\mathrm{R}^{2}[\mathrm{R}$ & $\begin{array}{l}\text { Conditions } \\
\text { Ru] }(\mathrm{mol} \%) \text {, Time }\end{array}$ & $\begin{array}{c}\text { Yield(\%) } \\
\text { (meta /ortho) }\end{array}$ \\
\hline $\mathrm{MeO}_{2} \mathrm{C}$ & $\mathrm{Me}$ & $\mathrm{Me}$ & $1.0,12 \mathrm{~h}$ & $92(92 / 8)$ \\
\hline \multirow{5}{*}{$\mathrm{MeO}_{2} \mathrm{C}$} & $\mathrm{Me}$ & $n-\mathrm{Bu}$ & $1.0,1 \mathrm{~h}$ & $85(93 / 7)$ \\
\hline & $\mathrm{Me}$ & $\widehat{\mathrm{OMe}}$ & $1.0,3 \mathrm{~h}$ & $86(94 / 6)$ \\
\hline & $\mathrm{Ph}$ & $n-B u$ & $10.0,24 \mathrm{~h}$ & $80(95 / 5)$ \\
\hline & TMS & $n-\mathrm{Bu}$ & $5.0,7 \mathrm{~h}$ & $94(95 / 5)$ \\
\hline & $\widehat{\mathrm{OMe}}$ & $n$-Bu & $1.0,3 \mathrm{~h}$ & $78(92 / 8)$ \\
\hline $\mathrm{TsN}$ & $\mathrm{Me}$ & $n-\mathrm{Bu}$ & $1.0,10 \mathrm{~min}$ & $83(93 / 7)$ \\
\hline 0 & $\mathrm{Me}$ & $n-B u$ & $1.0,30 \mathrm{~min}$ & $75(95 / 5)$ \\
\hline
\end{tabular}

16 電子ルテナサイクル中間体に取り込まれるアルキ ンに存在する 2 つの $\pi$ 電子のうち一方が金属中心と配 位相互作用して取り込まれると金属中心は配位的に飽和 となる。それと直交するもう一方のアルキン $\pi$ 軌道は メタラシクロペンタジエンの共役ジエン部位の方向にあ り[4+2]付加環化が 11 の遷移状態を経由して進行した と考えられる(スキーム 10)。

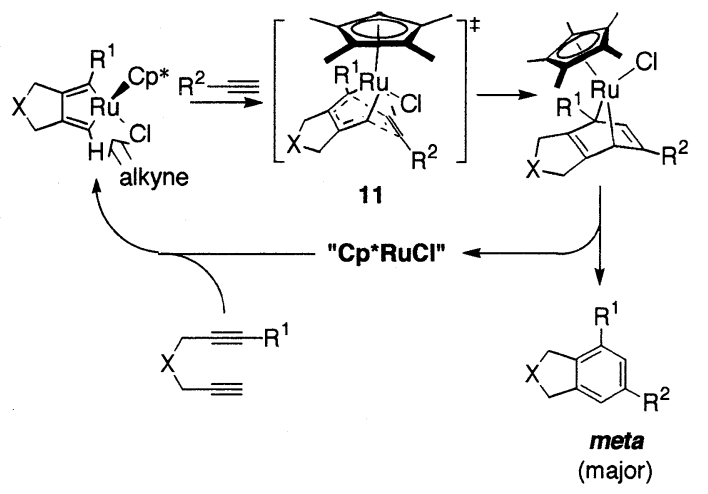

Scheme 10

\subsection{1,6-ジインと環状アルケンの付加環化}

$\mathrm{Cp}{ }^{*} \mathrm{RuCl}(\mathrm{cod})$ を触媒として，1,6-ヘプタジイン類と アルケンまたはシクロペンテンなどの環状アルケンを反 応させると，予想されるシクロへキサジエン誘導体はほ とんど生成せず，1,6-ヘプタジイン類の環化二-三量体 が主生成物となる。
しかし 2,5-ジヒドロフラン $13, N-$ トシル-2, 5-ジヒ ドロピロール 14, スルホラン 15 のような金属中心と配 位相互作用が可能な含酸素官能基を 4 位にもつ環状アル ケンを基質として用いると，1,6-ジイン 12 との触媒的 $[2+2+2]$ 付加環化が効率良く進行して対応する複素環 を縮環したシクロヘキサジエン誘導体 16,17, 18 が好収 率でえられることを見いだした(スキーム 11) 28 。
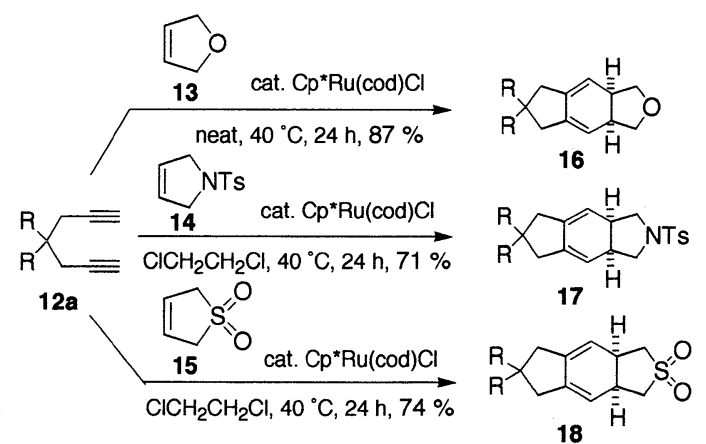

$\mathrm{R}=\mathrm{CO}_{2} \mathrm{CH}_{3}$

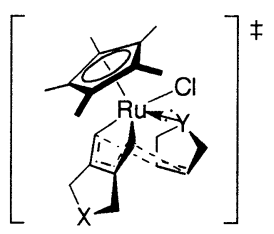

19

Scheme 11

酸素官能基を含む 5 員環アルケンが，効率良く付加環 化生成物を与える理由として高原子価 $[\mathrm{Ru}(\mathrm{IV})]$ のルテ ナシクロペンタジエンのルイス酸性によって，基質の酸 素官能基の非共有電子対が炭素結合形成反応に先立って 取り込まれたためと考えた(スキーム11 の下部に示した 19)。一方 cisoid 構造が構造的に不可能な 3-メトキシシ クロヘキセンを基質に用いた場合には，目的の触媒的付 加環化はもとより，ジインの二一三量化反応までも完全 に抑制された。この事実は基質のメトキシ部位が金属中 心と強く配位相互作用を受けるものの，アルケン部位が メタラサイクル中間体のジエン部位と $[4+2]$ 付加環化す べき位置を占めることが構造的に不可能であるためであ ると説明できる。すなわち基質の取り込みにへテロ原子 と高原子価金属中心の酸-塩基相互作用が重要であるこ とを示す。

これらの環化付加体は通常の Diels-Alder 反応におけ る環状共役ジエン成分として用いることができる。例え ば，スキーム 12 に示すように 1,6-ジイン 12 と 13 から 生成するジヒドロイソベンゾフラン型のシクロヘキサジ エン付加体 16 は, 無水マレイン酸と高収率で Diels-Alder 付加体 19 を生成する。基質として，Nフェニルマレイミド 20 を用いると，触媒的な $[2+2+2]$ 付加環化と付加体に対する Diels-Alder 反応がタンデム 的に進行し，高次付加環化生成物 21 が一挙に生成す 


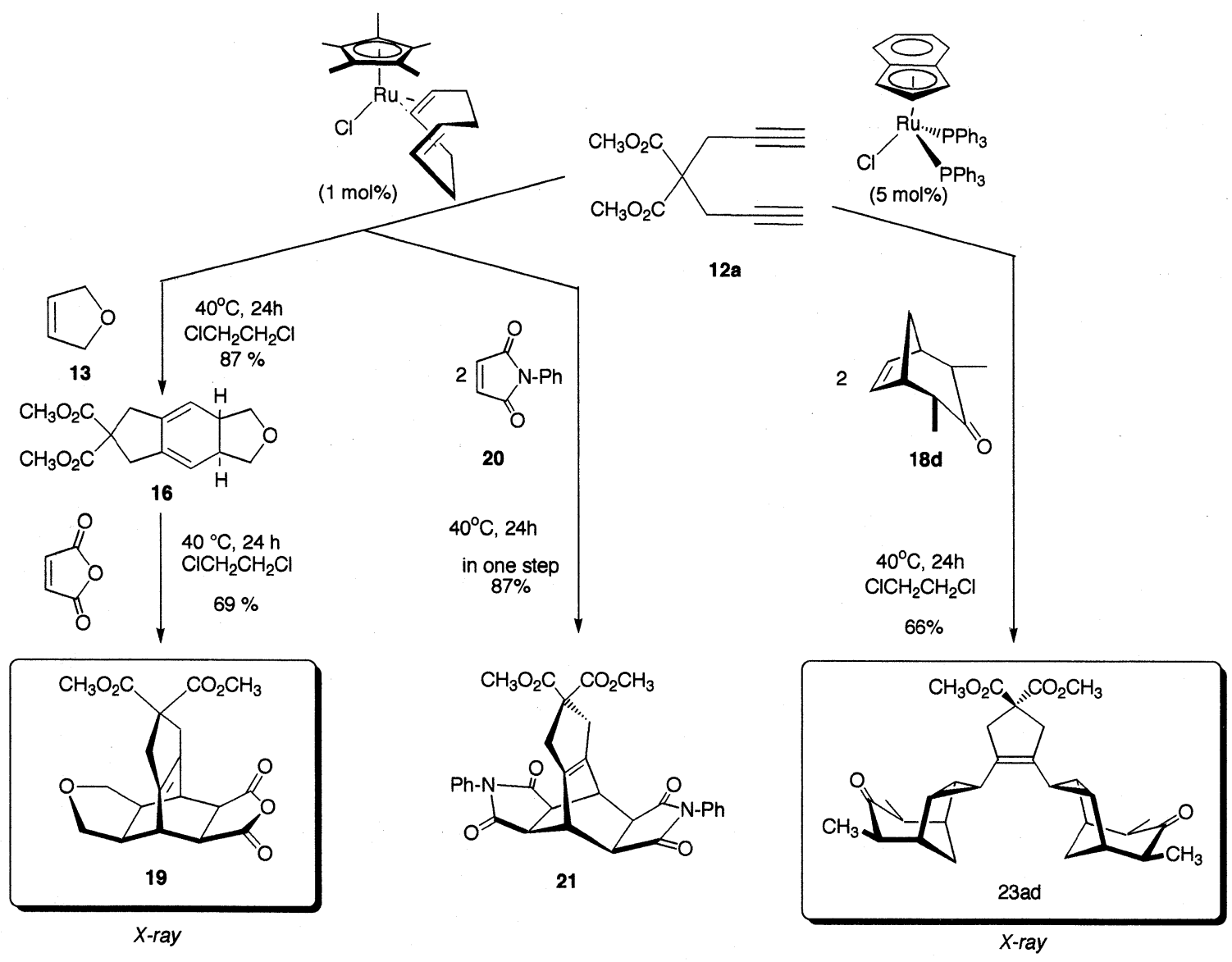

Scheme 12

$ろ^{28)}$ 。

1, 6-ジインと環状アルケンの触媒的付加環化におい て, 歪みをもつノルボルネン $18 \mathrm{a}$ を基質として用いた ところ, 予想した $[2+2+2]$ 付加環化生成物 22 aa の収 率は $47 \%$ に止まり副生成物として $1: 2$ 付加体 $23 \mathrm{aa}$ が $15 \%$ 程度, および過剰に用いているノルボルネンの開 環メタセシス重合により生じるポリマーが生成している ことが明らかになった(スキーム 13)。この $1: 2$ 付加体 $23 \mathrm{aa}$ の収率は, 支持配位子として Cp*のかわりに $\eta^{5}$ ー $\eta^{3}$ ハプトトロピー変化を容易に拉こし, 配位不飽和 度をさらに 2 電子分増加できるインデニル配位子を導入 することによって 78\%ににで向上させることに成功し

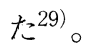

当初この高次付加体 $23 \mathrm{aa}$ は先に述べたマレイミドと の高次付加体 21 と同様の構造をもつと推定したが30), ビシクロ[3.2.1]アルケノン 18d を基質にして得られた $12 \mathrm{a}$ との付加環化生成物 $24 \mathrm{ad}$ の X 線構造解析の結果, 1,6-ジインの両末端炭素がともにカルベノイドとしてビ スシクロプロパン化した新たな高次タンデム付加環化生 成物であることが明らかになった $\left(\right.$ スキーム 12) ${ }^{29)}$ 。

この事実は，メタラシクロペンタジエン中間体 24 が その共鳴構造と考えられるメタラシクロペンタトリエン 25 として確実に挙動した最初の触媒的反応例である(ス
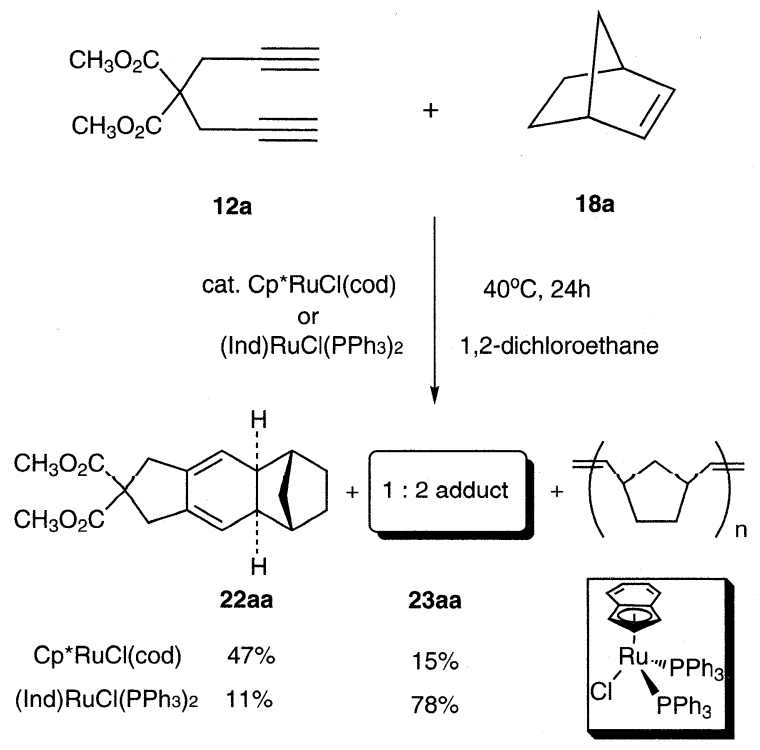

Scheme 13

キーム 14)。

これに関連して 2 分子のアルキンの酸化的環化により 合成されたルテニウムとオスミウムのメタラサイクル錯 体の X 線構造解析からメタラシクロペンタトリエン構 造が提案されている31)。

$6.31,6$-ジインとニトリルの位置選択的付加環化

極性官能基であるニトリルのシアノ基と金属との相互 
Table 2 Indenyl complex catalyzed tandem biscyclopropanation by 1,6-diyne as a biscarbenoid reagent.
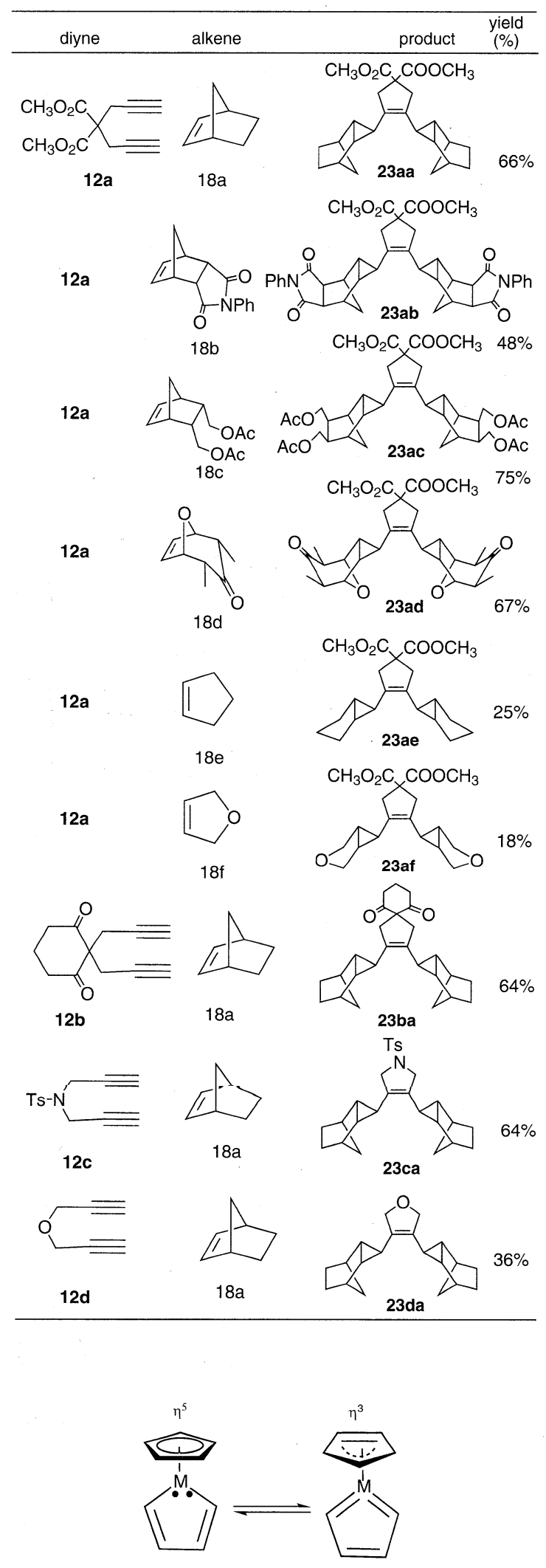

24

25

Scheme 14

作用は, 非共有電子対を使った直線的な $\eta^{1}$ 一直線型配位 が一般的である。この配位形式は，ニトリルを金属のル
イス酸性により求電子的に活性化することによって炭素 求核剤による分子間の炭素一炭素結合形成を目的とする 場合には有効な手段となっている。ルテニウム触媒反応 としては， $\eta^{1}$-配位したニトリルの $\alpha-\mathrm{C}-\mathrm{H}$ 結合の活性 化を利用した多様な縮合反応と水和反応が村橋らにより 活発に研究されておりメタロケテンイミン型中間錯体の 構造も小宮らにより報告された32)。

しかし直線状に $\eta^{1}$-配位されたニトリルの炭素求電子 中心と, 中心金属との距離が遠く離れるため付加環化形 式の結合形成には必ずしも有利ではない。付加環化には ニトリルが $\pi$ 配位した $\eta^{2}$ 一配位構造が望ましい。

分極した極性不飽和結合を $\eta^{2}$-配位した錯体として は，カルボニル基とルイス酸性が高く親酸素性にすぐれ た前期遷移元素の組み合わせの場合にはかなり知られて いるものの $\eta^{2}-$ シアノ錯体の例は必ずしも多くはな $\omega^{33)}$ 。

2 個のアルキンとニトリルとの $[2+2+2]$ 触媒的交差 付加環化によるピリジン合成の例としては，コバルト触 媒をもちいた山崎 ${ }^{7)}$, Bönnemannの分子間カップリン グ9)，および分子内化したシアノアルキンとアルキンの 反応例が報告されている ${ }^{10)}$ 。しかし分子間の 3 成分交差 カップリングでは, 非対称アルキンを用いた際の位置選 択性の制御が困難となる。また分子内化基質として適当 なテザーで調節したシアノアルキンを用いたアルキンと の付加環化は適用限界に問題を残していた。

$\mathrm{Cp}{ }^{*} \mathrm{RuCl}$ 活性種に 1,6-ジインを酸化的環化させ，生 成する 16 電子の 4 価ビシクロルテナシクロペンタジエ ン中間体がニトリルと $\eta^{2}$-シアノ錯体を形成できれば, さきに 7.1 で述べたアルキンとの交差カップリングに類 似した $[2+2+2]$ 付加環化が位置巽択的に進行し，ビシ クロピリジンの触媒的合成が可能になると考えた。

シアノ基の $\eta^{2}$-配位に有利と予想した電子求引基をも つニトリル類の 1, 6-ジインとの触媒反応を検討した(ス キーム 15) ${ }^{34)}$ 。両末端に置換基をもたないジイン $12 \mathrm{a}$ ， 12c，および $12 \mathrm{~d}$ では予想したように穏和な条件のもと でビシクロ $[4.3 .0]$ 構造をもつピリジン誘導体 27 が生成 した(表 3; entry 1-8；13-14)。また一方にメチルお よびフェニル置換基をもつ非対称ジインでは，アルキン との触媒的 $[2+2+2]$ 交差付加環化に比較して位置選択 性は若干低下するものの，置換基をもつ炭素にシアノ基 の窒素が結合したピリジン誘導体 27 をその位置異性体 28 に優先して生成した (entry 9-11)。しかし, ジイン の置換基に電子求引性のメトキシカルボニルをもつ非対 称ジインでは，反応が室温ですみやかに進行するととも に位置選択性が逆転する事実を発見した (entry 12)。そ の違いをもたらす原因はメタラサイクル形成段階にある と考えられる。すなわち, ジインの電子求引基をもつア 


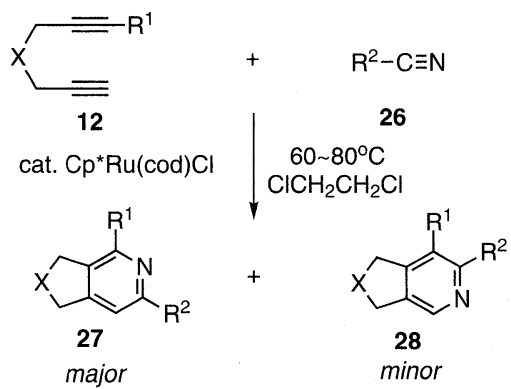

Scheme 15

Table 3 Catalytic formation of bicyclic pyridines from 1, 6 -diynes with the nitrile with electron-withdrawing groups.

\begin{tabular}{|c|c|c|c|c|c|c|c|c|}
\hline run & $x$ & $\mathrm{R}^{1}$ & $\mathrm{R}^{2}$ & $\begin{array}{l}\text { Cat. } \\
(\mathrm{mol} \%)\end{array}$ & $\begin{array}{l}\text { Temp } \\
\left({ }^{\circ} \mathrm{C}\right)\end{array}$ & $\begin{array}{c}\text { Time } \\
\text { (h) }\end{array}$ & $\begin{array}{c}\text { Yield } \\
(\%)\end{array}$ & $\begin{array}{l}\text { Regio- } \\
\text { selectivity }\end{array}$ \\
\hline \multirow{2}{*}{\multicolumn{2}{|c|}{$\begin{array}{l}1 \mathrm{C}\left(\mathrm{CO}_{2} \mathrm{CH}_{3}\right)_{2} \\
2 \mathrm{C}\left(\mathrm{CO}_{2} \mathrm{CH}_{3}\right)_{2}\end{array}$}} & $\mathrm{H}$ & $\mathrm{CO}_{2} \mathrm{Et}$ & 2 & 60 & 0.5 & 83 & 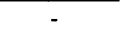 \\
\hline & & $\mathrm{H}$ & $\mathrm{COF}$ & & & & & 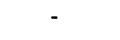 \\
\hline \multicolumn{2}{|c|}{$3 \mathrm{C}\left(\mathrm{CO}_{2} \mathrm{CH}_{3}\right)_{2}$} & $\mathrm{H}$ & $\mathrm{COCH}_{3}$ & 10 & & & & - \\
\hline \multicolumn{2}{|c|}{$4 \mathrm{C}\left(\mathrm{CO}_{2} \mathrm{CH}_{3}\right)_{2}$} & $\mathrm{H}$ & $\begin{array}{l}\text { CO- } \\
\text { furar }\end{array}$ & 5 & & 2 & & - \\
\hline \multicolumn{2}{|c|}{$5 \mathrm{C}\left(\mathrm{CO}_{2} \mathrm{CH}_{3}\right)_{2}$} & $\mathrm{H}$ & Ts & 10 & & 2 & & - \\
\hline \multicolumn{2}{|c|}{$6 \mathrm{C}\left(\mathrm{CO}_{2} \mathrm{CH}_{3}\right)_{2}$} & $\mathrm{H}$ & $\mathrm{CCl}_{3}$ & 10 & & 24 & & - \\
\hline \multicolumn{2}{|c|}{$7 \mathrm{C}\left(\mathrm{CO}_{2} \mathrm{CH}_{3}\right)_{2}$} & $\mathrm{H}$ & $\mathrm{C}_{5} \mathrm{~F}_{5}$ & & & & & - \\
\hline \multicolumn{2}{|c|}{$8 \mathrm{C}\left(\mathrm{CO}_{2} \mathrm{CH}_{3}\right)_{2}$} & $\mathrm{H}$ & $\mathrm{C}_{7} \mathrm{~F}_{15}$ & 5 & & 1 & & \\
\hline \multirow{3}{*}{\multicolumn{2}{|c|}{$\begin{array}{r}9 \mathrm{C}\left(\mathrm{CO}_{2} \mathrm{CH}_{3}\right)_{2} \\
10 \mathrm{C}\left(\mathrm{CO}_{2} \mathrm{CH}_{3}\right)_{2} \\
11 \mathrm{C}\left(\mathrm{CO}_{2} \mathrm{CH}_{3}\right)_{2}\end{array}$}} & $\mathrm{CH}_{3}$ & $\mathrm{CO}_{2} \mathrm{Et}$ & 5 & 60 & 2 & 75 & $88: 12$ \\
\hline & & $\mathrm{CH}_{3}$ & COPh & 10 & 80 & 24 & 47 & \\
\hline & & $\mathrm{Ph}$ & $\mathrm{CO}_{2} \mathrm{Et}$ & 10 & 80 & 20 & 34 & $99: 1$ \\
\hline \multicolumn{2}{|c|}{$12 \mathrm{C}\left(\mathrm{CO}_{2} \mathrm{CH}_{3}\right)_{2}$} & $\mathrm{CH}$ & $\mathrm{H}_{3} \mathrm{CO}_{2} \mathrm{Et}$ & t 5 & rt. & 1 & 78 & $13: 87$ \\
\hline 13 & $\mathrm{~N}-\mathrm{Ts}$ & $\overrightarrow{\mathrm{H}}$ & $\mathrm{CO}_{2} \mathrm{Et}$ & 2 & 60 & 0.5 & 75 & - \\
\hline 14 & 0 & $\mathrm{H}$ & $\mathrm{CO}_{2} \mathrm{Et}$ & 2 & 60 & 2 & 49 & - \\
\hline
\end{tabular}

ルキン炭素末端とニトリルが酸化的環化することによっ て，これまでのメタラシクロペンタジエン中間体とは異 なりアザルテナシクロペンタジエン中間体を形成するた めと考えている。

一方, $\mathrm{Cp}{ }^{*} \mathrm{RuCl}$ を触媒とする様々な置換パターンを もつ 1, 6-ジインと, 環状アルケン類との触媒的 $[2+2+$ 2]交差付加環化を検討していた過程で，4-位に2つの シアノ基をもつ 1,6-ジインだけが目的とする $[2+2+2]$ 付加環化生成物を生成せず，シアノ基を含む複雑な混合 物を生じることを発見した。その原因を追及するためマ ロノニトリルと種々の 1, 6-ジインとの触媒反応を検討 することにした。その結果，マロノニトリル 29a，フマ ロニトリル $29 \mathrm{c}$, フタロニトリル $29 \mathrm{~d}$ のように分子内 に近接した複数のシアノ基をもつジシアニド類の一方の シアノ基のみが，1,6-ジイン $12 \mathrm{a}, 12 \mathrm{c}, 12 \mathrm{~d}$ と高選択的 に[2+2+2]交差付加環化し，2-位にシアノ基を含む置 換基をもつピリジン誘導体 30 を高収率で生成すること を発見した $\left(\right.$ スキーム 16 ${ }^{35)}$ 。

この反応系が，村橋らによって報告されたニトリルの 縮合反応における中間体を与える $\alpha-\mathrm{C}-\mathrm{H}$ 結合の活性化 を経由する可能性を検証するため，29a の C-H 結合を ジベンジル化してブロックした 2, 2-ジシアノ-1, 3-ジ フェニルプロパン $29 \mathrm{~b}$ を基質にして $12 \mathrm{a}$ と反応させた
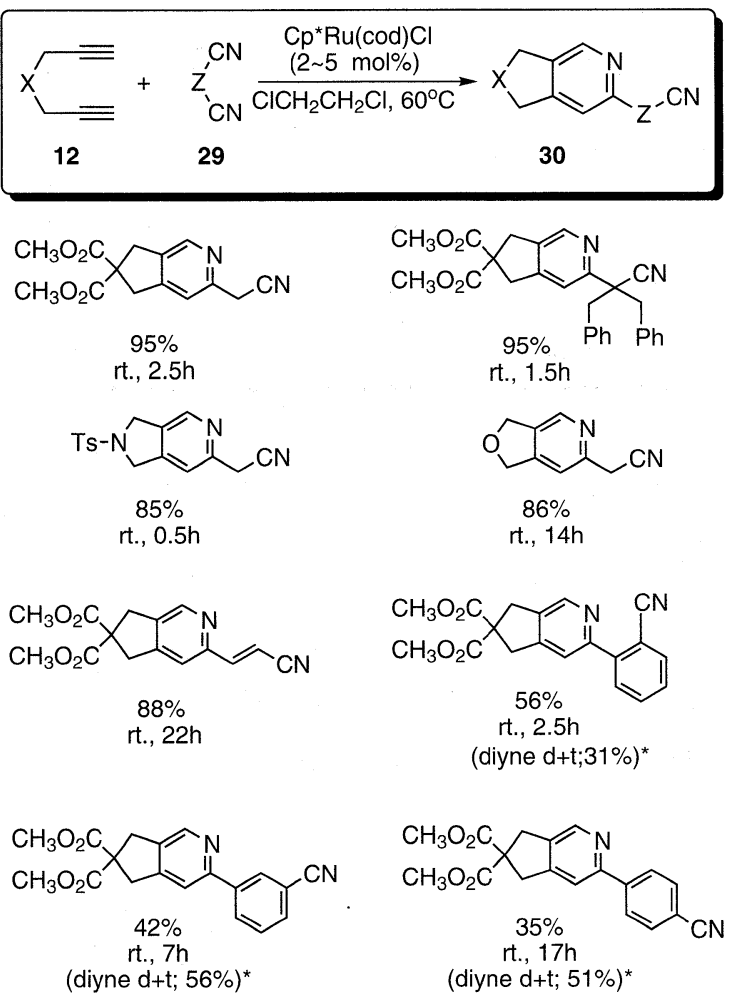

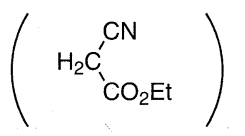

31

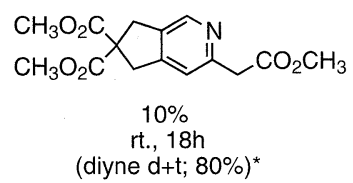

(diyne $\mathrm{d}+\mathrm{t} ; 80 \%)^{*}$ *diyne $d+t$ means the combined yield of the dimer and the trimer of the employed diyne.

Scheme 16

ところ，マロノニトリル $29 \mathrm{a}$ と全く同様に対応する $[2$ $+2+2]$ 付加環化生成物を高収率で生成した。また $2 つ$ のシアノ基間の距離が長くなるに従ってピリジン誘導体 の収率は急速に低下することも明らかになった。

しかしマロノニトリルの 2 つのシアノ基の片方が， シ アノ基と同様に電子求引性を示すエトキシカルボニル基 に変わったシアノ酢酸エチル 31 を基質に用いた場合に は，触媒的カップリングによるピリジン骨格形成はごく わずかしか起こらず，ジインの二一三量化が主として進 行する。さらにコバルト触媒の代表的な基質であるベン ゾニトリルやアセトニトリルのような一般的なニトリル 誘導体も, このルテニウム触媒系ではピリジン誘導体を ほとんど生成しなかった。

非対称構造をもつ 1, 6-ジイン類を基質に用いた場合 には，ニトリルの窒素原子が置換基をもつ1,6-ジイン の炭素と結合した位置異性体 32 を, 極めて高い位置選 択性で生成することを見いだした(スキーム 17)。

このジニトリル類に特異的な触媒的 $[2+2+2]$ 付加環 化の反応機構は現在のところ明らかではないが, ジニト リルが架橋配位子として作用した複核ルテニウム配位子 

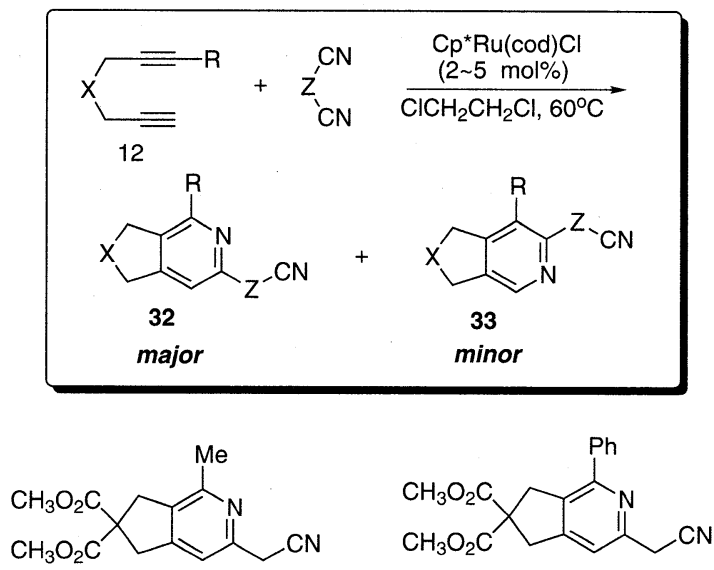

$97 \%(95: 5)$

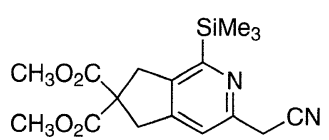

$92 \%(100: 0)^{b}$

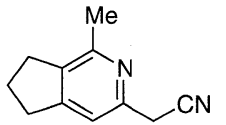

$97 \%(100: 0)$

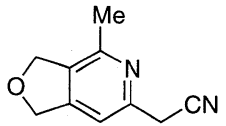

$97 \%(95: 5)$

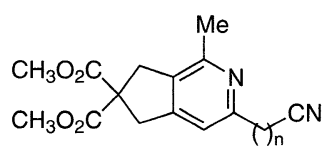

$\mathrm{n}=2 ; 73 \%(100: 0)$

$\mathrm{n}=3 ; \quad 5 \%(100: 0)$

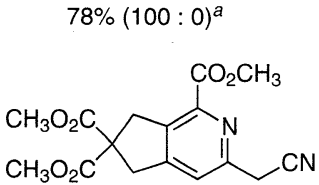

$70 \%(100: 0)$

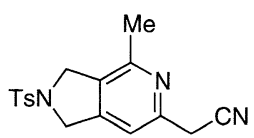

$95 \%(100: 0)$

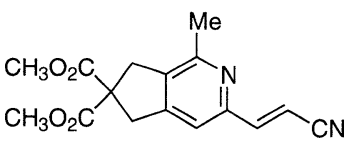

$88 \%(100: 0)$

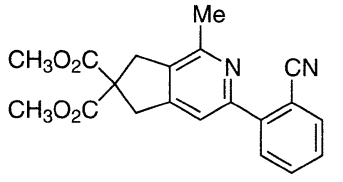

$88 \%(100: 0)$

a With $10 \mathrm{~mol} \%$ of cat. The diyne was recovered $(11 \%)$. $b$ The reaction proceeded at room temperature.

Scheme 17

場が関与していると現在推定している。

本反応の特徵として化学的に等価な 2 つのアノ基の 片方のみが選択的にピリジン骨格を形成することが挙げ られる。この特異な選択性は $1: 1$ および $1: 2$ 付加体を 混合物として生成するコバルト触媒とは大きく異なる。

これらの $\mathrm{Cp}{ }^{*} \mathrm{RuCl}$ 触媒のピリジン合成の高い化学選 択性と位置選択性の利点を活かして，2,2'-ジピリジル 合成への展開をはかった。すなわち $12 \mathrm{a}$ を二量化して 得られる 1, 6, 8, 13-テトライン 34 を基質として $29 \mathrm{a}$ お よび $29 \mathrm{~b}$ と反応させたところ，それぞれ対応する $2,2^{\prime}-$ ジピリジル誘導体 $35 \mathrm{a}$ および $35 \mathrm{~b}$ を一段の反応操作で 効率的に合成することに成功した（スキーム 18）。この 方法はジニトリルの代わりに末端アルキンを用いれば, 多置換ビフェニル誘導体合成にも応用できる。

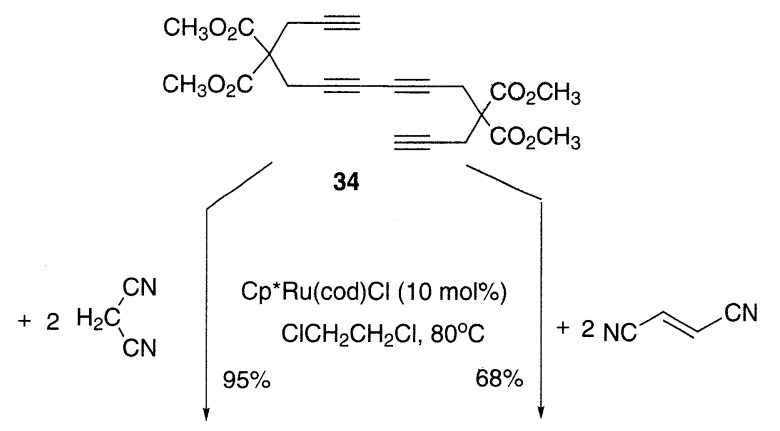

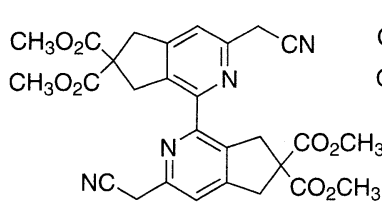

$35 a$

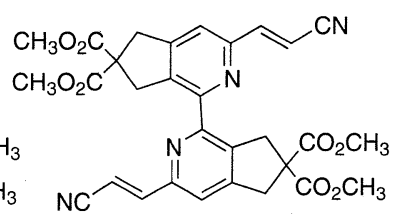

35b
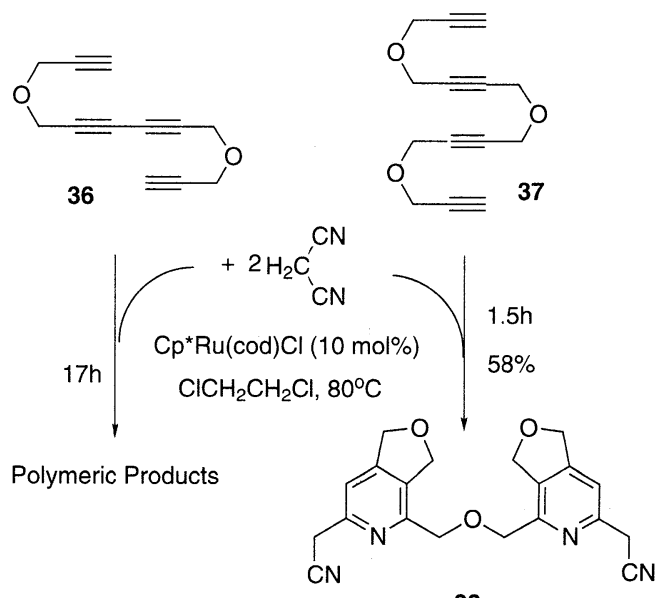

38

Scheme 18

しかしジプロパルギルエーテルを二量化して合成した テトライン 36 では尒想したジピリジル誘導体は全く生 成しなかった。しかし，36の中央部にスペーサーをは さんだテトライン 37 からは，29a との反応によりピリ ジン骨格がそれぞれ独立に形成され38を生成した ${ }^{36)}$ 。

\subsection{1,6-ジインとへテロクムレンとの付加環化}

2 分子のアルキンとイソシアナートの触媒的な $[2+2$ $+2]$ 交差付加環化によって2-ピリドン骨格を触媒的に 構築する反応は山崎とVollhardt らによるコバルト触媒 および Hobergによるニッケル触媒の例が既知であ $3^{37,38)}$ 。この反応のアルキン基質として 1,6-ジイン誘 導体が用いられた例は筆者の知る限りほとんど見られな い。コバルト触媒を用いて $1,7-$ ，または 1,6 -ジインと ニトリルを反応させ，極めて低収率で 2-ピリドンが生 成した報告があるに過ぎなかった。

そこで $\mathrm{Cp} * \mathrm{RuCl}(\mathrm{cod})$ を触媒として 1,6-ジイン 12 と フェニルイソシアナート 39 を，添加方法に若干の工夫 を加えて，還流 1,2-ジクロロエタン.中で反応させたと ころ，短時間で対応する 2-ピリドン 40 が触媒的に合成 
できた ${ }^{39)}$ 。ソシアナートとしては芳香族に限らずシク ロヘキシルおよびベンジルイソシアナートなどにも適用 可能である。1,6-ジイン成分としては，4-位が無置換， 窒素，または酸素置換された基質でも効率良く反応は進 行し，対応する2-ピリドン誘導体を得ることができる (スキーム 19)。

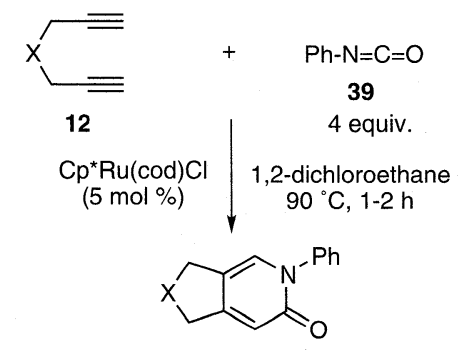

40

a $\mathrm{X}=\mathrm{C}\left(\mathrm{CO}_{2} \mathrm{Me}\right)_{2}, 1 \mathrm{~h}, 87 \%$; b $\mathrm{X}=\mathrm{CH}_{2}, 2 \mathrm{~h}, 62 \%$;

c $X=N T s, 1 h, 82 \%$; $X=0,2 h, 58 \%$

Scheme 19

基質にイソチオシアナートを用いた $[2+2+2]$ 付加環 化の触媒プロセスはこれまで例はなく，山崎らのコバル タシクロペンタジエンとメチルイソチオシアナートの量 論反応により，わずか $10 \%$ 収率で付加環化体が得られ ているに過ぎなかった。そこで1,6-ジインとイソチオ シアナート 41 の $\mathrm{Cp}{ }^{*} \mathrm{RuCl}(\mathrm{cod})$ 触媒 10\% 存在下の反応 を $90^{\circ} \mathrm{C}$ で行った(スキーム 20)。フェニルおよびエトキ
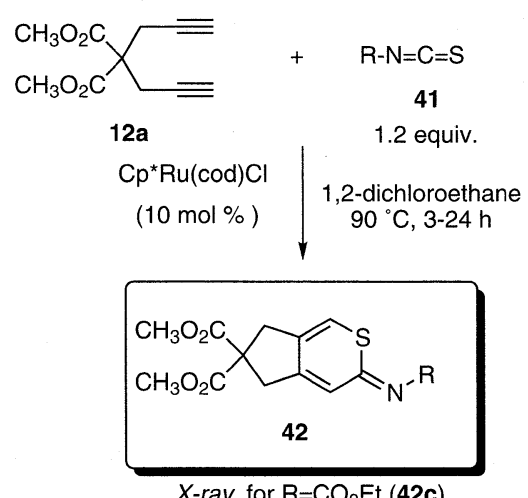

$X$-ray for $\mathrm{R}=\mathrm{CO}_{2} \mathrm{Et}(\mathbf{4 2 c})$

a $\mathrm{R}=\mathrm{Ph}, 5 \mathrm{~h}, 88 \%$; b $\mathrm{R}=\mathrm{COPh}, 24 \mathrm{~h}, 76 \%$; c $\mathrm{R}=\mathrm{CO}_{2} \mathrm{Et}, 3 \mathrm{~h}, 71 \%$

Scheme 20

シカルボニルイソチオシアナート $(41 \mathrm{a}$ および $41 \mathrm{c})$ を基 質とした場合に，それぞれ 88 および $71 \%$ の収率で $\mathrm{C}=$ $\mathrm{S}$ 結合が選択的に $[2+2+2]$ 付加環化した，対応する

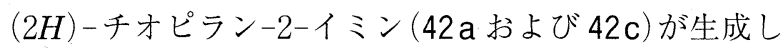
た ${ }^{40)}$ 。この反応はチオピラン骨格の触媒的構築法として 興味深い。さらに $12 \mathrm{a}$ と二硫化炭素との反応も合わせ 検討し，50\%の単離収率でジチオピロンを得ることも できた40)。

謝 辞 本論文の骨子となるジインの付加環化を全面的 に立案実行し，大きな貢献をされた山本芳彦博士に深甚
なる謝意を表する。また，ここに示した多くの実験を精 力的に情熱をもって進めてくれた北原秀幸氏，小川龍治 氏，永田麻子さん，高岸秀行君，奥田聡君をはじめとす る，筆者の研究室で実験に協力された多くの学生諸君の 努力に深く感謝する。

さらに, 本研究の発端となったパラジウム触媒反応に 貢献された，鈴木寛治博士，西山久雄博士，および平井 憲次博士，そしてルテニウム (IV)の有機金属化学を確 立された永島英夫博士，共役ジエンの反応で困難な実験 を忍耐強く行った深堀隆彦博士と増田克之博士に感謝す る。また二官能性基質の面白さを教えられた松田勇助教 授に謝意を表したい。

本研究の多くは，文部省，文部科学省，および日本学 術振興会の科学研究費補助金により行った成果であり, その資金援助に感謝する。また三菱化学株式会社, 東 ソー株式会社からもご援助をいただいた。併せて謝意を 表する次第である。

(2001 年 8 月 24 日受理)

\section{文 献}

1）この分野の代表的な成書：(a)へゲダス遷移金属による有機 合成, L.S. Hegedus 著。村井真二訳, 東京化学同人, 2001; (b) "Comprehensive Organometallic Chemistry II", Vol. 12, ed. by L. S. Hegedus, Pergamon Press, Oxford, 1995; (c) "Transition Metals for Organic Synthesis" in two volumes, eds. by M. Beller. C. Bolm, Wiley-VCH Verlag, 1998; (d) J. Tsuji, "Transition Metal Reagents and Catalysts" John Wiley and Sons Inc., Chiechester, U. K. 2000; (e) G. W. Parshall, S. D. Ittel, "Homogeneous Catalysis", Second Edition, John Wiley and Sons Inc., New York, 1992; (f) K. C. Nicholaou, E. J. Sorensen, "Classics in Total Synthesis", VCH, 1996, p 154-165; 358-379; 566-599; 全合成の鍵とな る遷移金属反応の概要が要領良くまとめられていて便利であ る。

2) (a) K. J. Ivin, J. C. Mol, "Olefin Metathesis and Metathesis Polymerization" Academic Press, San Diego, 1997; (b) A. Fürstner ed., "Alkene Metathesis in Organic Synthesis" , Vol 1 of Topic in Organometallic Chemistry, Springer, 1998; (c) R. H. Grubbs, S. Chang, Tetrahedron, 54, 4413 (1998); (d) T. M. Trunka, R. H. Grubbs, Acc. Chem. Res., 34, 18 (2001); (e) A. Kinoshita, M. Mori, J. Org. Chem., 61, 8356 (1996); (f) A. Kinoshita, N. Sakakibara, M. Móri, J. Am. Chem. Soc., 119, 12368 (1997)

3) R. H. Crabtree, "The Organometallic Chemistry of the Transition Metals", Third ed., John Wiley and Sons, Inc, New York, 2001

4) K. Tamao, "Comprehensive Organic Synthesis" , Vol. 3, eds. by B.M. Trost, I. Fleming, Pergamon Press, 1991, p 413-480 : K. Sonogashira, ibid., p 521-562

5) (a) W. Reppe, O. Schlichting, K. Klager, T. Tropöl, Justus Liebigs Ann. Chem., 560, 1 (1948); (b) G. Wilke, Pure and Appl. Chem., 50, 677 (1978)

6) (a) P. W. Jolly, G. Wilke, "The Organic Chemistry of Nickel", in two volumes, Academic Press, New York, 1975; (b) G. Wilke, Angew. Chem., Int. Ed. Engl., 27, 185 (1988); (c) W. Keim, A. Behr, M. Roper, "Comprehensive Organometallic Chemistry", Vol. 8, eds. by E. W. Abel, F. G. A. Stone, G. Wilkinson, Pergamon Press, Oxford, 1982, p 371-460; (d) 
“Comprehensive Organic Synthesis", Vol. 5, eds. by B. M. Trost, I. Fleming, Pergamon Press, Oxford, 1991

7) (a) H. Yamazaki, N. Hagihara, J. Organometal. Chem., 7, P 22 (1967); (b) Y. Wakatsuki, H. Yamazaki, J. Chem. Soc., Chem. Commun., 1973, 280; (c) idem, J. Organomet. Chem., 139, 157 and 169 (1977); (d) idem, Tetrahedron Lett., 1973, 36 ; idem, ibid., 1974, 4549; idem, Synthesis, 1976, 26; idem, J. Chem. Soc., Dalton Trans, 1978, 1278; (e) P. Hong, H. Yamazaki, Tetrahedron Lett., 1977, 1333; idem, Synthesis, 1977, 50; 山崎博史，有合化, 45, 244 (1983)

8） 総説:N. E. Shore, Chem. Rev., 88, 1081 (1988); eds. by B. M. Trost, I. Fleming, "Comprehensive Organic Synthesis" , Vol. 5, Pergamon Press, Oxford, 1991. p 1037; "Comprehensive Organometallic Chemistry II", Vol. 12, ed. by L. S. Hegedus, Pergamon Press, Oxford, 1995, p 703

9) H. Bönnemann, Angew. Chem., Int. Ed. Engl., 17, 505 (1978), 総説 : idem, ibid., 24, 248 (1985)

10) (a) R. L. Funk, K. P. C. Vollhardt, J. Am. Chem. Soc., 99, 5483 (1977); (b) 総説 : K. P. C. Vollhardt, Acc. Chem. Res, 10, 1 (1977); idem, Angew. Chem., Int. Ed. Engl., 23, 539 (1984)

11）メタラシクロペンタジエンおよびメタラシクロヘプタトリエ ン錯体 : (a) For Rh: E. Müller. Synthesis, 1974, 761; idem, Tetrahedron Lett., 1976, 1789; (b) For Pd: K. Moseley, P. M. Maitlis, J. Chem. Soc., Chem. Commun., 1971, 1604; idem, J. Chem. Soc., Dalton Trans., 1974, 169; (c) T. Ito, Y. Hasegawa, Y. Takahashi, Y. Ishii, J. Chem. Soc., Chem. Commun., 1972, 629; idem, J. Organomet. Chem., 73, 401 (1973); (d) J. Browning, M. Green, B. R. Penfold, J. L. Spencer, F. G. A. Stone, J. Chem. Soc., Chem. Commun., 1973, 31; (e) J. Browning, M. Green, J. L. Spencer, F. G. A. Stone, J. Chem. Soc., Dalton Trans., 1974, 97; (f) Y. Wakatsuki, K. Aoki, H. Yamazaki, J. Am. Chem. Soc., 96, 5284 (1974)

12）本論文の一部は，一昨年 11 月発行の本協会誌英文号に掲載 された。ここでは最近の研究成果を含めて説明する：K. Itoh, I. Matsuda, Y. Yamamoto, 有合化, 57, 913 (1999)

13) H. Suzuki, K. Itoh, Y. Ishii, K. Simon, J. A. Ibers, J. Am. Chem Soc., 98, 8494 (1976)

14) L. D. Brown, K. Itoh, H. Suzuki, K. Hirai, J. A. Ibers, J. Am. Chem. Soc., 100, 8232 (1978)

15) Y. Yamamoto, A. Nagata, K. Itoh, Tetrahedron Lett., 40, 5035 (1999)

16) Y. Yamamoto, A. Nagata, Y. Arikawa, K. Tatsumi, K. Itoh, Organometallics, 19, $2403(2000)$

17) K. Itoh, F. Ueda, K. Hirai, Y. Ishii, Chem. Lett., 1977, 877

18) K. Itoh, K. Hirai, M. Sasaki, Y. Nakamura, H. Nishiyama, Chem. Lett., 1981865

19) (a) H. Nagashima, K. Mukai, K. Itoh, Organometallics, 3 , 1314 (1984); (b) 伊藤健兒，永島英夫，深堀隆彦，日化， 1991, 177

20) (a) H. Nagashima, K. Mukai, K. Itoh, H. Suzuki, N. Oshima, Y. Moro-oka, Organometallics, 4, 1314 (1985); (b) H. Nagashima, K. Mukai, Y. Shiota, K. Yamaguchi, T. Fukahori, H. Suzuki, M. Akita, Y. Moro-oka, K. Itoh, ibid., 9, 799 (1990)

21) (a) H. Nagashima, K. Yamaguchi, K. Mukai, J. Organomet. Chem., 319, C 11 (1987); (b) H. Nagashima, T. Oshima, K. Itoh, Chem. Lett., 1983, 789 and 792

22) H. Nagashima, K. Yamaguchi, K. Mukai, K. Itoh, J. Organomet. Chem., 291, C 20 (1985)
23) (a) K. Masuda, K. Nakano, T. Fukahori, H. Nagashima, K. Itoh, J. Organomet. Chem., 428, C 21 (1992); (b) K. Masuda, H. Ohkita, S. Kurumatani, K. Itoh ibid., 454, C 13 (1992)

24) K. Itoh, K. Masuda, T. Fukahori, K. Nakano, K. Aoki, H. Nagashima, Organometallics, 13, 1020 (1994)

25) (a) K. Itoh, K. Mukai, H. Nagashima, H. Nishiyama, Chem. Lett., 1983, 499; (b) H. Nagashima, H. Matsuda, K. Itoh, J. Organomet. Chem., 258, C 15 (1983); (c) K. Itoh, H. Nagashima, N. Oshima, H. Nishiyama, ibid., 272, 179 (1983)

26）ルテニウム錯体を用いる触媒的炭素結合形成と付加環化：(a) T. Mitsudo, K. Kokuryo, Y. Watanabe, Y. Takegami, $J$. Chem. Soc., Chem. Commun., 1976, 722; (b) T. Mitsudo, H. Naruse, T. Kondo, Y. Ozaki, Y. Watanabe, Angew. Chem., Int. Ed. Engl., 44, 580 (1994); (c) T. Kondo, N. Suzuki, T. Okada, T. Mitsudo, J. Am. Chem.. Soc., 119, 6187 (1997); (d) T. Morimoto, N. Chatani, Y. Fukumoto, S. Murai, J. Org. Chem., 62, 3762 (1997); (e) T. Mitsudo, T. Suzuki, S. W. Ahang, D. Imai, K. Fujita, T. Manabe, M. Shiotuka, Y. Watanabe, K. Wada, T. Kondo, J. Am. Chem. Soc., 121, 1839 (1999); (f) Review: T. Mitsudo, T. Kondo, Synlett., 2001, 309; (g) 近藤輝幸，有合化， 59, 170 (2001)

27) Y. Yamamoto, R. Ogawa, K. Itoh, Chem. Commun., 2000, 549

28) Y. Yamamoto, H. Kitahara, R. Ogawa, K. Itoh, J. Org. Chem., 63, 9610 (1998)

29) Y. Yamamoto, H. Kitahara, R. Ogawa, H. Kawaguchi, K. Tatsumi, K. Itoh, J. Am. Chem. Soc., 122, 4310 (2000)

30) Y. Yamamoto, H. Kitahara, R. Hattori, K. Itoh, Organometallics, 17, 1910 (1998)

31) (a) M. O. Albers, D. J. A. de Waal, D. C. Lilies, D. J. Robinson, E. Singleton, M. B. Wiege, J. Chem. Soc., Chem. Commun., 1986, 1680; (b) L. Pu, T. Hasegawa, S. Parkin, H. Taube, J. Am. Chem. Soc., 114, 2712 (1992); idem, ibid., 114, 7609 (1992); (c) C. S. Lin, J. R. Torres-Lubian, N. Liu, Organometallics, 17, 1257 (1998); (d) J. La Paih, S. Derion, P. H. Dixneuf, Chem. Commun., 1999, 1437

32） 総説 : (a) T. Naota, H. Takaya, S.-I. Murahashi, Chem. Rev., 98, 2599 (1998)および引用文献; (b) S.-I. Murahashi, H. Takaya, Acc. Chem. Res., 33, 225 (2000); (c) S. -I. Murahashi, T. Naota, H. Taki, M. Mizuno, H. Takaya, S. Komiya, Y. Mizuho, N. Oyasato, M. Hiraoka, M. Hirano, J. Am. Chem. Soc., 117, 12436 (1995)

33） $\eta^{2}$-ニトリル錯体の例：(a) T. C. Wright, G. Wilkinson, M. Motevalli, M. B. Hursthouse, J. Chem. Soc., Dalton Trans., 1986, 2017; (b) P. A. Chetcuti, C. B. Knobler, M. F. Hawthorne, Organometallics, 7, 650 (1988); (c) J. Barrera, M. Sabat, W. D. Harman, ibid., 12, 4381 (1993); (d) J. L. Kiplinger, A, M, Arif, T. G. Richmond, Chem. Commun., 1996, 1691; idem, Organometallics, 16, 246 (1997)

34) Y. Yamamoto, S. Okuda, K. Itoh, Chem. Commun., 2001, 1102

35) Y. Yamamoto, R. Ogawa, K. Itoh, J. Am. Chem. Soc., 123, $6189(2001)$

36） Y. Yamamoto, R. Ogawa, K. Itoh，未発表

37) R. A. Earl, K. P. C. Vollhardt, J. Org. Chem., 49, 4786 (1984)

38) For Ni: H. Hoberg, B. W. Oster, Synthesis, 1982, 324

39) Y. Yamamoto, H. Takagishi, K. Itoh, Org. Lett., 3, 2117 (2001)

40) Y. Yamamoto, H. Takagishi, K. Itoh, J. Am. Chem. Soc., 印 刷中; 18th International Symposium on Heterocyclic Chemistry, Yokohama; 30 PO 87, abstract p 220, July, 2001 

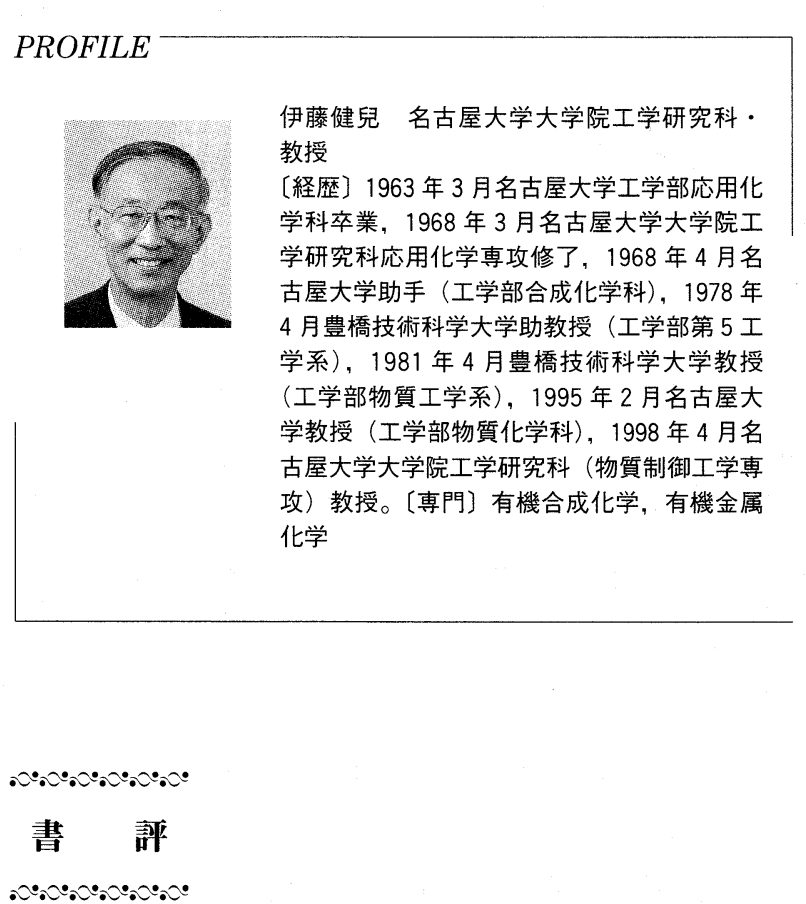

\section{ビギナーズ有機化学}

川端 潤 著

B 5 変型判 $\cdot 168$ 頁 定価 2,200 円(税別) 化学同人

本書は大学初年次の化学系学生あるいは化学系以外の 学生や社会人の学習に向けて書かれた有機化学の入門的 教科書である。本書は筆者の講義を基に作られていると 思われ，「有機化学の基本的な考え方をしっかりと学ん で欲しい」という著者の真摰な気持が伝わってくる。

社会を見回すと有機材料は現在の物質文明を支えてい る立役者であることが分かる。有機化学はその基盤を支 える科学である。したがって多くの人が有機化学をしっ かりと理解することが必要である。にも拘わらず有機化 学は嫌われている。これは有機化学が丸暗記の科目と認 識されていることも一因と思われる。本書はそれを払拭 すべく「少数の基礎原理を使いこなせば有機化学は容易 に理解できる」という主張の具現化を目指している。化 学を専門としない方々にとってはむしろそういう力こそ が必要で, 特に物質の危険性を予想できる能力は社会で 指導的な立場に立つ人材にとって久かせないであろう。

本誌の読者の多くは有機合成化学の専門家であろう が，その仕事の 1 つとして有機化学を他分野の人に理解 してもらうための努力という極めて重要な責務がある。 それを急れば，理科嫌い，理科軽視など日本の空洞化の 流れのなかで起きている梁刻な事態を後押しすること になってしまう。特にある分野で専門家を目指す高等教
育機関で学ぶ学生，周辺分野の技術者一できれば社会科 学分野の人にも一に有機化学をよく理解してもらう努力 が必要であろう。その意味でも本書の意義は大きいだ ろう。

とは言うものの私自身は本書への要望も持っている。 まず化学を専門としない方への教科書における化学構 造式の描き方についてである。有機化学の文法といえる 化学式や電子の流れなどの描き方を厳密に説明している ことは大きく詊㑋できる。しかし化学の分野では標準で もそれをそのまま化学系以外の方への説明に使用するの は適切だろうか。原子省略法の丁寧な説明は非常に役立 つ一方，省略しなければもっと分かりやすいと考えられ る構造式もある。また立体配座の取り扱い(メチレン鎖, シクロアルカン)が反応より先に登場する構成は学習意 欲の維持の面で疑問がある。さらに問題の解答例，少な くとも解答の指針がぜひほしい。これが充実すれば広く 支持される教科書になると期待できる。

最後に，平衡の矢印の「両かぎ」には違和感を持った。 多く教科書でもこうなっているがやはり，片かぎ矢印の 対で表すのが筋であろうと思っている。

（米澤宣行） 